This PDF is a selection from a published volume from the National Bureau of Economic Research

Volume Title: American Universities in a Global Market

Volume Author/Editor: Charles T. Clotfelter, editor

Volume Publisher: University of Chicago Press

Volume ISBN: 0-226-11044-3; 978-0-226-11044-8

Volume URL: http://www.nber.org/books/clot08-1

Conference Date: October 2-4, 2008

Publication Date: May 2010

Chapter Title: Is the United States Losing Its Preeminence in Higher Education?

Chapter Author: James D. Adams

Chapter URL: http://www.nber.org/chapters/c11592

Chapter pages in book: (33 - 68) 


\title{
Is the United States Losing Its Preeminence in Higher Education?
}

\author{
James D. Adams
}

\subsection{Introduction}

For more than fifty years, US universities have led the world in research and graduate education, building on firm foundations laid down in the nineteenth century, and rising to new heights during the twentieth century. But in recent years doubts have begun to arise concerning the future of US higher education, considered as a producer of graduate and professional students as well as scientific discoveries. The two are complementary: faculty that are not at the research frontier are less likely to produce top PhDs and MDs, and conversely, faculty who lack top students are less likely to do cutting-edge research. It follows that this chapter's emphasis on research extends to advanced students. ${ }^{1}$ Furthermore, a strong research enterprise improves the quality of undergraduate education in the long run and contributes to the ability to undertake advanced training. As far as higher education is concerned, none of this is new.

The United States is losing share in scientific research, and perhaps in papers accepted in top journals (Hicks 2007), in part because the number of countries that devote significant resources to scientific research has

James D. Adams is professor of economics at Rensselaer Polytechnic Institute and a research associate of the National Bureau of Economic Research.

The Andrew W. Mellon and Alfred P. Sloan Foundations supported data collection underlying this project. I thank Charles Clotfelter, Charles Phelps, two readers, and conference participants for comments. The staff of Folsom Library, Rensselaer Polytechnic Institute, provided valuable assistance in locating the historical data discussed in this paper. Of course, I am responsible for any remaining errors. This paper was presented at the NBER Conference on American Universities in a Global Market held in Woodstock, Vermont, October 2-4, 2008.

1. In confirmation of this point, the National Research Council rankings of graduate programs reveal a strong positive correlation between research and the quality of graduate programs. See National Research Council (1995). 
increased. This implies intensified competition for scientific and engineering talent and also greater competitiveness of foreign high technology firms (Freeman 2006). But in addition to growth overseas, a slowdown has taken place within the United States. The growth rate of financial resources of US public universities has declined and this has reduced the growth rate in their publications. ${ }^{2}$ This development is important, because public universities account for a large share of US science.

It may come as a surprise to hear that US universities could be in danger of losing their preeminence, since top US private and public universities invariably rank near the pinnacle of world institutions (Shanghai Jiao Tong University 2005). But university growth overseas implies that this dominance may not last forever. Moreover, public universities in the United States have struggled in recent years.

To understand how top private universities in the United States have reached unparalleled heights at the same time that top public universities have fallen behind, it is necessary to explain the organization of US higher education. It is a mixed public-private system. Top US private universities rely on federal grants, endowments, gifts, and tuition to hire the best faculty, select the best students, and sustain their competitive advantage. In this they are not constrained by state interests. The situation is otherwise with US public universities, whose charter, beginning with the Morrill Act of 1862, enjoins them to support state industries by providing affordable and practical higher education. If state budgets contract, or if competition for state funds strengthens, then funding diminishes and the competitive advantage of US public universities declines. A pillar of public support for higher education, its accountability to state interests erodes and becomes a constraint on university growth. In recent years this appears to have taken place.

The chapter's focal point is a panel of universities and fields observed over time. Main findings from an analysis of these data are as follows. Starting with growth facts, I find that research output grows at about the same rate in the late twentieth century in private schools as in public, until the 1990s, when public university growth slows down. This is despite the fact that stocks of Research and Development (R\&D), which are mostly federally funded, rise appreciably faster in public universities. A slowdown in papers and in papers per dollar of R\&D is evident in the late 1990s, again in public universities. Given the challenges of measuring R\&D, I provide faculty counts as a supplementary measure. It turns out that faculty grow at a slower rate than papers, so research productivity indeed rises. Once again, though, it rises more slowly in public universities, especially during the late 1990s. In addition, the evidence reveals that current funds rise more rapidly in private universities, suggesting that in public universities, faster growth of (mostly federal) R\&D stocks is cancelled by slower growth in tuition and state appropriations. Hence, faster growth of current funds in private 
schools contributes to faster growth of wages and research output in these universities.

Continuing with regression findings, I show that public and private universities obtain similar percentage increases in scientific papers and citationweighted papers from equal (percentage) increases in $R \& D$, graduate students, and current funds, so that differences in growth of research output between the two sets of institutions are the result of differences in growth of resources. Here private universities have recently held the advantage. Departments ranked in the top 20 percent of their disciplines obtain a larger increase in papers for the same increase in $R \& D$ and students than departments of lower rank. Graduate students contribute more to papers in top 20 percent departments than elsewhere, suggesting the high degree of complementarity of faculty and graduate students at the top of the quality distribution.

Compensation in private universities rises faster than it does in public universities by almost 1 percent per year. Compared to public universities, where the wage structure is relatively flat, compensation in private schools is higher at all ranks and rises more markedly for full professors. This suggests incentives for researchers, especially senior researchers, to migrate from public to private universities. Combined with slower growth in current funds in public universities, this helps to produce slower growth in their research output than in that of private universities.

The rest of the chapter proceeds as follows. Sections 1.2 and 1.3 provide an historical perspective on US universities. Section 1.2 recounts the expansion of research in US universities before, during, and after World War II. This is the period in which US universities progress relative to the rest of the world. Section 1.3 considers the US contribution to world scientific output since the 1980s. The share of the United States declines sharply during this period. While this is inevitable in the face of post-war recovery and world economic development, the section also points to a slowdown in research output during the 1990s in the United States, due largely to a deceleration in the growth rate of resources in US public universities.

Section 1.4 introduces panel data covering 110 top US universities and twelve main science fields during 1981 to 1999 . Section 1.5 presents growth facts concerning university research. Section 1.6 begins with regressions in which research output is the dependent variable and concludes with wage regressions. Section 1.7 discusses the evidence and draws conclusions for the future of US higher education.

\subsection{US Universities Since World War II}

\subsubsection{Pre-War Setting}

Prior to World War II and unlike the present day, federal R\&D was located inside the US military (Mowery and Rosenberg 1989, 92 ff.). Agri- 
cultural research is the exception. It was conducted in land-grant colleges founded by the Morrill Act of 1862 and the Land-Grant Act of 1890, extending the 1862 Act to state agricultural and mechanical colleges for blacks. In addition, the Hatch Act of 1887 established experiment stations close to the land-grant colleges. Huffman and Evenson (1993, ch. 1) provide a summary of these developments. ${ }^{3}$

The first statistical evidence on university $R \& D$ in the United States derives from balance sheet data in 1935 and 1936. The data are contained in Research-A National Resource, Volume I (National Resources Committee 1938, section 6). ${ }^{4}$ A survey of sixty universities yielded total research expenditures of $\$ 50$ million. Of this amount, $\$ 16$ million was earmarked for experiment stations, much of this funded by the Department of Agriculture. ${ }^{5}$ Of the remaining $\$ 34$ million, seventeen derived from endowment, eight from foundations, four from gifts, two from contract research, and two from state government. Therefore, the federal government's main role in university research was its support for agriculture.

Bush $(1945,86)$ contains estimates of research expenditure by sector from the 1930s through World War II. The data are limited to natural science. ${ }^{6}$ Using as a basis the figure of $\$ 50$ million reported in National Resources Committee (1938), this yields $\$ 25$ million for natural science research in 1936. Using survey data on research faculty, this figure is then extrapolated backward to 1930 and forward to 1942 to arrive at natural science R\&D for universities. This is the relatively crude university series shown in figure 1.1. ${ }^{7}$

The aforementioned summarizes the pre-war setting. Events surrounding World War II led to a vast expansion of university R\&D. First, before the war, immigration of scientists from Europe significantly increased the science and engineering workforce. Second, during the war, a sharp rise in defense research increased the demand for scientists and engineers, which the Cold War institutionalized. ${ }^{8}$ Third, after the war, the GI Bill helped

3. The democratic and equal-opportunity conditions set by the early US patent system (Khan 2005) may have complemented the later establishment of universities focused on the agricultural and mechanical arts - the very type envisaged by the Morrill Act.

4. Individual evidence on university R\&D exists before 1935 to 1936 . The University of Chicago conducted an internal survey of research costs in 1929 and 1930 and the University of California undertook a similar survey in 1928 and 1929. But these data lack the comparative breadth of the National Resources Committee survey.

5. In 1940 federal R\&D expenditures were $\$ 74$ million, of which $\$ 29$ million or 39 percent, consisted of Department of Agriculture R\&D (Mowery and Rosenberg 1998, 27). Clearly, agricultural research assumed a much larger role in the federal government and universities than it does today.

6. In these early data, natural science includes biological, mathematical, and physical science, plus engineering.

7. Industrial R\&D statistics are obtained by multiplying industrial researchers by R\&D per worker of $\$ 4,000$. See Research-A National Resource, Volume II (National Resources Committee 1941, section IV).

8. By an increase in demand I mean throughout a shift to the right of the demand curve for scientists and engineers. 


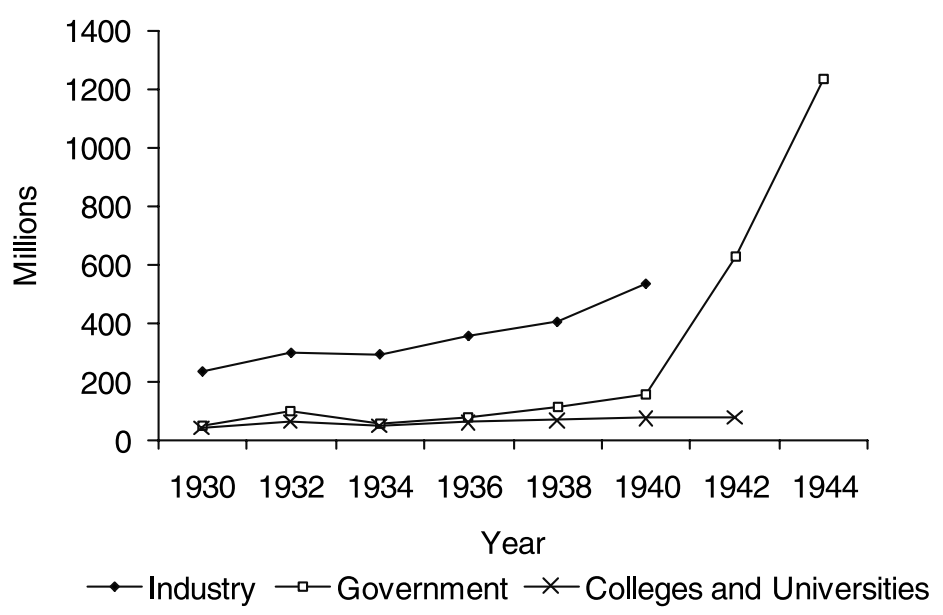

Fig. 1.1 R\&D in the United States, 1930-1944 (millions of 1958 dollars)

Sources: R\&D dollars, Bush (1945, 86); implicit GDP deflator, US Department of Commerce, Bureau of the Census (1975, part 1, series E13).

finance college education for returning soldiers, which subsequently produced a spike in enrollments and increased post-war demand for faculty. I discuss each of these factors in turn.

\subsubsection{The Intellectual Migration from Europe, 1933-1944}

The supply of highly skilled scientists to the United States increased due to the flight from Hitler's Europe, but by how much, and in what proportion? The main statistical source is Davie (1947), who directed data collection for the Committee for the Study of Recent Immigration from Europe. ${ }^{9}$ Using the criterion of "refugee, arrival from Europe as place of last residence," statistics of immigration and naturalization yielded 22,842 refugees in the professions during 1933 to 1944 . The refugees were assigned to detailed occupations: 507 were chemists, 2,471 engineers, 3,415 professors and teachers, and 1,907 were "scientists or literary persons," yielding a total of 8,300 refugees in science, engineering, and related professions. In 1938 the National Resources Committee, using American Men of Science, 6th edition (1938), estimated that 28,000 US men and women were researchers in the natural sciences, and that 22,000 more were in the humanities and social sciences (National Resources Committee 1938, 171) for a total of 50,000 across all sectors of the economy. ${ }^{10}$ Thus, while the intellectual migration from Europe during the 1930s was small by modern standards, it was large

9. Fermi (1971) recounts individual biographies of this wave of immigrants by detailed occupation, including scientists and engineers by their separate specialties. Her time period, 1930 to 1941, is earlier than that of Davie (1947), whose perspective I adopt here.

10. The committee judged that of the existing stock of 50,000 researchers, 5,000 or (10 percent) were in the first rank. 
for the time. Put another way, if half of the roughly 8,000 refugees in science and engineering and related fields were engaged in research - not excessive, given their occupations - then this constitutes an increase of 4,000 persons on a base of 50,000 , or 8 percent. And since they specialized in natural science and engineering, then the increase could be almost 4,000 on a base of 28,000 , or 14 percent. ${ }^{11}$

There is reason to think that even this understates growth at the highest levels of research. Table 1.1 illustrates. ${ }^{12}$ Twelve refugees had won a Nobel Prize by 1947, the most prestigious international award. ${ }^{13}$ Using a sample collected by Davie (1947) of 707 refugees who served on university faculties in Europe, 203 persons were accounted distinguished in their disciplines, of which 181 were in natural science. To assess the meaning of this, turn to table 1.2, which compiles US-resident Nobel Prize winners by decade. The number of foreign-born is shown in parentheses for each subject area, except for the sum across areas, where the foreign-born appear as column (2) ${ }^{14}$ Noting that twenty-three prizes had been won by US residents by 1940 , with none foreign-born except for one award, I conclude that the intellectual migration from Europe increased resident Nobel Prize winners by 50 percent. ${ }^{15}$

Table 1.2 also shows that major improvements in US universities were under way by the 1930s. Across areas, the number of native-born prizes rises from one to seventeen per decade during 1901 to 1940 . Excluding economics prizes - since these did not exist until 1969 - the total of seventeen prizes for the 1930s is half the native-born total, per decade, during 1971 to 2007.

\subsubsection{Increase in Federal R\&D During World War II}

Besides the increase in the pre-war supply of highly skilled scientists and engineers, the increase in military R\&D during and after the war produced a sustained rise in demand for scientists and engineers. Figures 1.1 and 1.2 illustrate. $^{16}$

Figure 1.1 shows R\&D expressed in millions of 1958 dollars in industry, government, and colleges and universities during 1930 to 1944 . The data are

11. Following the usage of Bush (1945) and Davie (1947), in this section natural science refers to biology, medicine, mathematics and statistics, and engineering, in addition to chemistry and physics.

12. The data are compiled from appendix C of Davie (1947).

13. The Fields Medal in mathematics dates from 1936 and competes with the Abel and Wolf prizes. Other awards of distinction, such as the National Medal of Science in the United States, are national in scope.

14. In this table, Nobel Prizes in science include chemistry, physics, and physiology or medicine.

15. The foreign-born award belongs to Albert A. Michelson, for the Michelson-Morley experiment on the invariance of the speed of light.

16. The data on federal $R \& D$ are of higher quality during this period than the data on academic and industrial $R \& D$, because they derive from annual cost accounts. All these data are crude by standards of the present day. 


\begin{tabular}{|c|c|c|c|}
\hline Field & $\begin{array}{l}\text { Nobel Prize } \\
\text { winners }^{\mathrm{a}}\end{array}$ & $\begin{array}{l}\text { Distinguished } \\
\text { refugees }^{\mathrm{b}}\end{array}$ & $\begin{array}{l}\text { Sample of refugee } \\
\text { professors }^{\mathrm{c}}\end{array}$ \\
\hline Biology; physiology or medicine & 2 & 72 & 91 \\
\hline Chemistry & 1 & 28 & 63 \\
\hline Physics or astronomy & 6 & 40 & 77 \\
\hline Mathematics & n.a. & 41 & 53 \\
\hline Literature & 3 & 15 & 65 \\
\hline Economics & n.a. & 7 & 60 \\
\hline Total & 12 & 203 & 409 \\
\hline
\end{tabular}

Note: n.a. $=$ not applicable.

${ }^{a}$ These are Nobel Prize winners by the time of Davie (1947).

'Distinguished Refugees are compiled by Davie (1947, 432-40), from Who's Who in America (1944-1945) and American Men of Science (1944).

'Sample consists of 707 refugees in Davie (1947) who were formerly on university faculties in Europe, of which 409 were in the disciplines shown.

Table 1.2

Nobel Prizes won by US residents, 1901-2007

\begin{tabular}{|c|c|c|c|c|c|c|}
\hline Period & $\begin{array}{c}\text { Total } \\
\text { laureates }\end{array}$ & $\begin{array}{c}\text { Total } \\
\text { (foreign- } \\
\text { born) }\end{array}$ & $\begin{array}{c}\text { Science }^{\mathrm{a}} \\
\text { (foreign- } \\
\text { born) }\end{array}$ & $\begin{array}{l}\text { Literature } \\
\text { (foreign- } \\
\text { born) }\end{array}$ & $\begin{array}{c}\text { Peace } \\
\text { (foreign- } \\
\text { born) }\end{array}$ & $\begin{array}{c}\text { Economics }^{\mathrm{b}} \\
\text { (foreign- } \\
\text { born) }\end{array}$ \\
\hline 1901-1910 & 2 & 1 & $\begin{array}{c}1 \\
(1)\end{array}$ & 0 & 1 & n.a. \\
\hline $1911-1920$ & 3 & 0 & 1 & 0 & 2 & n.a. \\
\hline 1921-1930 & 5 & 0 & 2 & 1 & 2 & n.a. \\
\hline 1931-1940 & 13 & 0 & 9 & 2 & 2 & n.a. \\
\hline 1941-1950 & 22 & 5 & $\begin{array}{l}15 \\
(5)\end{array}$ & 2 & 5 & n.a. \\
\hline 1951-1960 & 29 & 7 & $\begin{array}{l}27 \\
(7)\end{array}$ & 1 & 1 & n.a. \\
\hline 1961-1970 & 32 & 10 & $\begin{array}{c}27 \\
(10)\end{array}$ & 1 & 3 & 1 \\
\hline 1971-1980 & 52 & 14 & $\begin{array}{l}40 \\
(7)\end{array}$ & $\begin{array}{c}3 \\
(3)\end{array}$ & $\begin{array}{c}1 \\
(1)\end{array}$ & $\begin{array}{c}8 \\
(3)\end{array}$ \\
\hline 1981-1990 & 48 & 15 & $\begin{array}{c}37 \\
(11)\end{array}$ & $\begin{array}{c}1 \\
(1)\end{array}$ & $\begin{array}{c}1 \\
(1)\end{array}$ & $\begin{array}{c}9 \\
(2)\end{array}$ \\
\hline 1991-2000 & 52 & 12 & $\begin{array}{l}39 \\
(9)\end{array}$ & 1 & 1 & $\begin{array}{l}11 \\
(3)\end{array}$ \\
\hline 2001-2007 & 46 & 9 & $\begin{array}{l}31 \\
(6)\end{array}$ & 0 & 2 & $\begin{array}{l}13 \\
(3)\end{array}$ \\
\hline All years & 304 & 73 & $\begin{array}{l}229 \\
(56)\end{array}$ & $\begin{array}{l}12 \\
(4)\end{array}$ & $\begin{array}{l}21 \\
(2)\end{array}$ & $\begin{array}{c}42 \\
(11)\end{array}$ \\
\hline
\end{tabular}

Note: n.a. $=$ not applicable.

${ }^{a}$ Science Nobel Prizes include separate awards in physics, chemistry, and in physiology or medicine.

${ }^{b}$ The Nobel Prize in economics began in 1969. Thus, economics prizes for the 1961 to 1970 decade are limited to 1969 and 1970. Data compiled from Nobel Archives at www.nobel.org. 


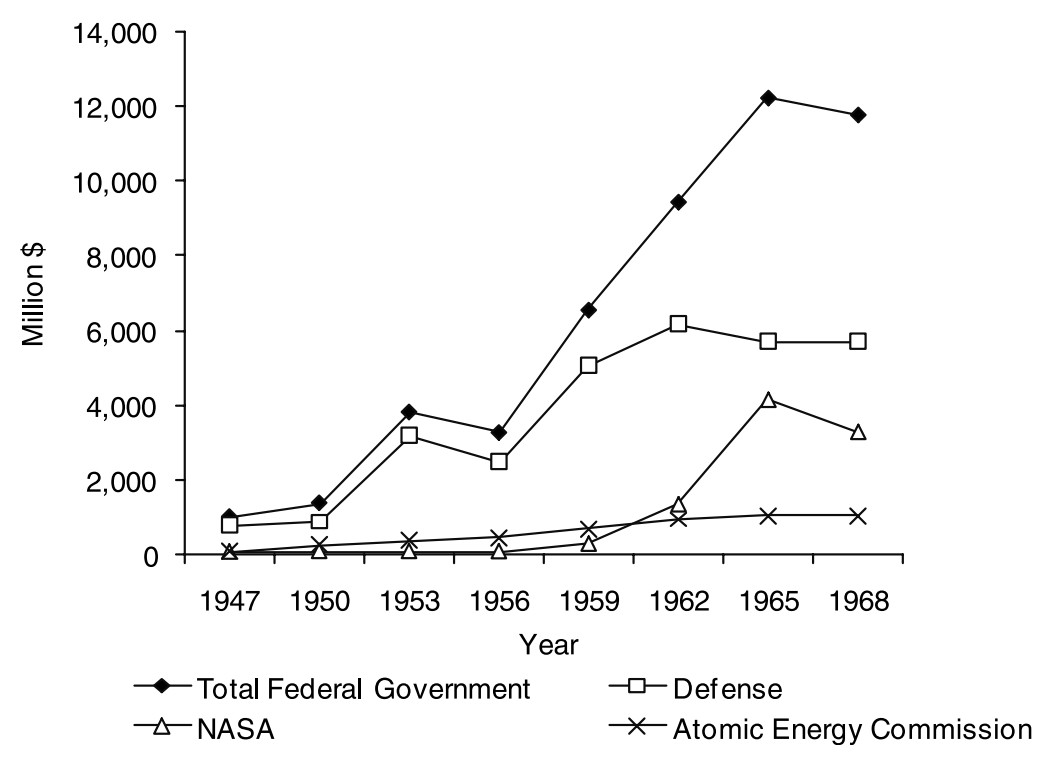

Fig. 1.2 Federal R\&D, 1947-1968 (millions of 1958 dollars)

Sources: R\&D dollars, US Department of Commerce, Bureau of the Census (1975, part 2, series W126, W129, W137, and W138); implicit GDP deflator, US Department of Commerce, Bureau of the Census (1975, part 1, series E13).

reported every two years. ${ }^{17}$ They show that federal $R \& D$ rises from less than 200 million in 1940 to over 1.2 billion by 1944 .

To the benefit of US universities the Cold War produced a sustained rise in the demand for scientists and engineers. Figure 1.2 shows Federal R\&D in 1958 dollars for the years 1947 to $1968 .^{18}$ Total federal R\&D amounted to $\$ 1$ billion in 1947 , rising to $\$ 12$ billion by 1968 . Nearly all R\&D expenditures were on defense, the Atomic Energy Commission, or NASA.

\subsubsection{Post-War Demand for Higher Education}

Mobilization produced a wartime decline in male college enrollment and degrees. But under the GI Bill this decline was succeeded by a large spike around 1950. Figure 1.3 shows BA and BS degrees from 1932 to $1960 .{ }^{19}$ Baccalaureate degrees earned by men rise during the 1930s, then decline from a peak of 100,000 in 1940 to a trough of 50,000 in 1946, and finally spike to 350,000 in 1950 . By comparison, the decline and recovery of degrees

17. To convert current into constant dollars I have used the implicit GDP deflator with 1958 set to 1.0. This chart, as I have noted, derives from Bush $(1945,86)$.

18. The source of the R\&D data is US Department of Commerce, Bureau of the Census (1975, Part 2, series W 126, 129, 137, and 138). These are deflated by the implicit GDP deflator for government purchases of goods and services (indexed to 1958) that appears in US Department of Commerce, Bureau of the Census (1975, Part 1, series E 13).

19. The data on BA and BS degrees derive from US Department of Commerce, Bureau of the Census (1975, Part 1, series H 752-754). 


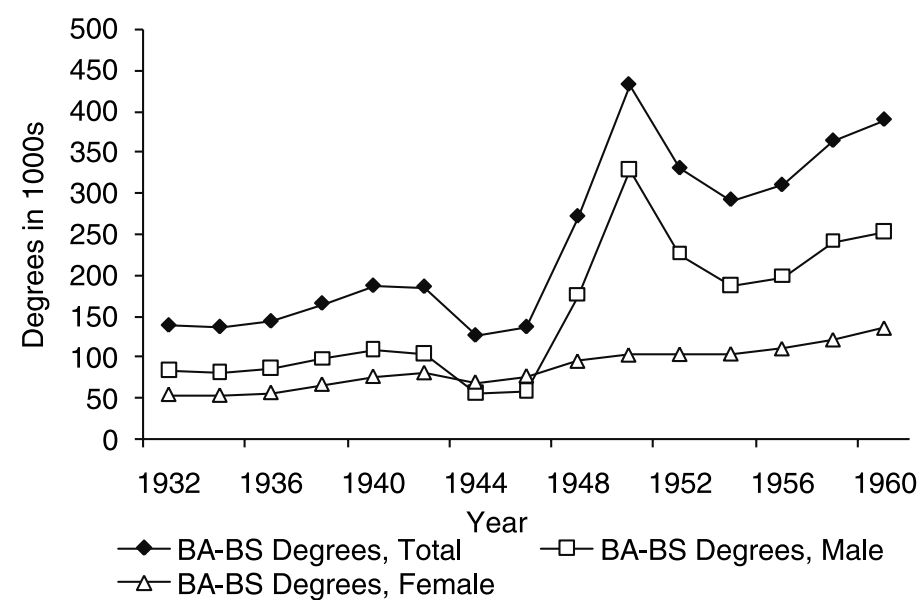

Fig. 1.3 Baccalaureate degrees in the United States, 1932-1960

Source: US Department of Commerce, Bureau of the Census (1975, part 1, series H752-H754).

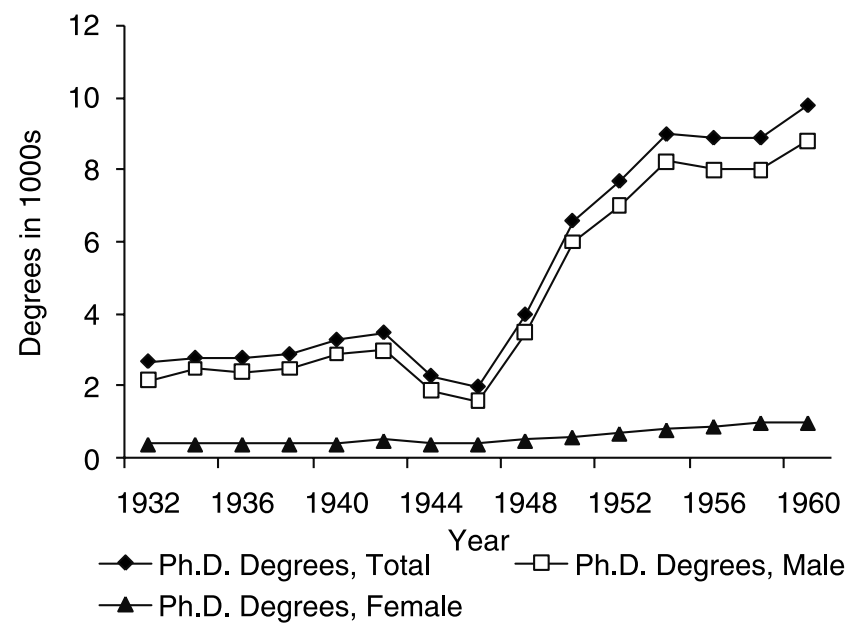

Fig. 1.4 PhD degrees in the United States, 1932-1960

Source: US Department of Commerce, Bureau of the Census (1975, part 1, series H761-H763).

earned by women are slight. As the stock of excess demand for education diminished during the 1950s, baccalaureate degrees fell and did not regain their 1950 peak until the mid-1960s.

Figure 1.4 shows $\mathrm{PhD}$ degrees from 1932 to $1960 .{ }^{20}$ These increase from 2,000 to almost 4,000 during the 1930 s, decline to 2,000 by 1946 , and increase

20. The data on PhD degrees derive from US Department of Commerce, Bureau of the Census (1975, Part 1, series H 761-763). 
to 10,000 in 1960 . Unlike baccalaureate degrees, the flow of PhDs rises smoothly, reflecting the strength of long-run prospects for advanced skills.

World War II and the Cold War led to sustained growth in US academic science. Throughout the subsequent period, growing demand for undergraduate and graduate education fueled continued expansion of US universities.

\subsection{World Scientific Output Since the 1980s}

Having discussed forces that led to expansion of research in US universities from the 1930s to the 1980s, I now examine the recent role of the United States in world scientific research. I shall use scientific papers as a measure of the public or "commons" aspects of science. ${ }^{21}$ Figure 1.5 shows relative growth of papers in the United States compared to the EU-15 group of European countries, East Asia, and rest of the world. ${ }^{22}$ Clearly, US papers grow slowly compared to most regions, and growth equals zero from 1997 to 2002. The EU-15 countries surpass the United States in total publications by 1997 and they maintain this lead into the twenty-first century. East Asia grows more rapidly than any other region, including the EU-15, but it does so from a small base.

Figure 1.6 constructs regional shares in world scientific publications over the period 1988 to 2005. Definitions of the regions differ slightly from figure 1.5. ${ }^{23}$ The EU-23 supersedes the EU-15 and the Asia-10 countries replace East Asia. ${ }^{24}$ On these broader definitions, Europe's share of world scientific papers surpasses that of the United States in 1996. The US share falls from 38 percent to 29 percent during this period. The EU-23 share peaks in 1998 but then declines. All shares decline except Asia-10, with the US decline the fastest of all.

Figures 1.7 through 1.9 display regional shares in world citations in 1992, 1997, and 2003. ${ }^{25}$ The charts show an accelerating decline in the US share of citations, though nowhere is this as great as the decline for papers. The EU-15 gain share; and the share of East Asia, while it is small, grows the

21. Alternative measures of commercial licenses and patents are beyond the scope of this chapter.

22. The EU-15 consists of Austria, Belgium, Denmark, Finland, France, Germany, Greece, Ireland, Italy, Luxembourg, Netherlands, Portugal, Spain, Sweden, and the United Kingdom. These are the EU countries before the addition of countries of Eastern Europe. East Asia consists of Japan, China, South Korea, Singapore, and Taiwan. The source of figure 1.5 is appendix table 41, chapter 5, National Science Board (2006).

23. The source of these data is appendix table 41, chapter 5, National Science Board (2006) and appendix table 34, chapter 5, National Science Board (2008).

24. The EU-23 countries are the EU-15 plus new member countries Bulgaria, Czech Republic, Estonia, Latvia, Lithuania, Poland, Romania, and Slovenia. The Asia-10 countries consist of East Asia (Japan, China, South Korea, Singapore, and Taiwan) plus India, Indonesia, Malaysia, Philippines, and Thailand.

25. The data source is appendix table 61, chapter 5, National Science Board (2008). 


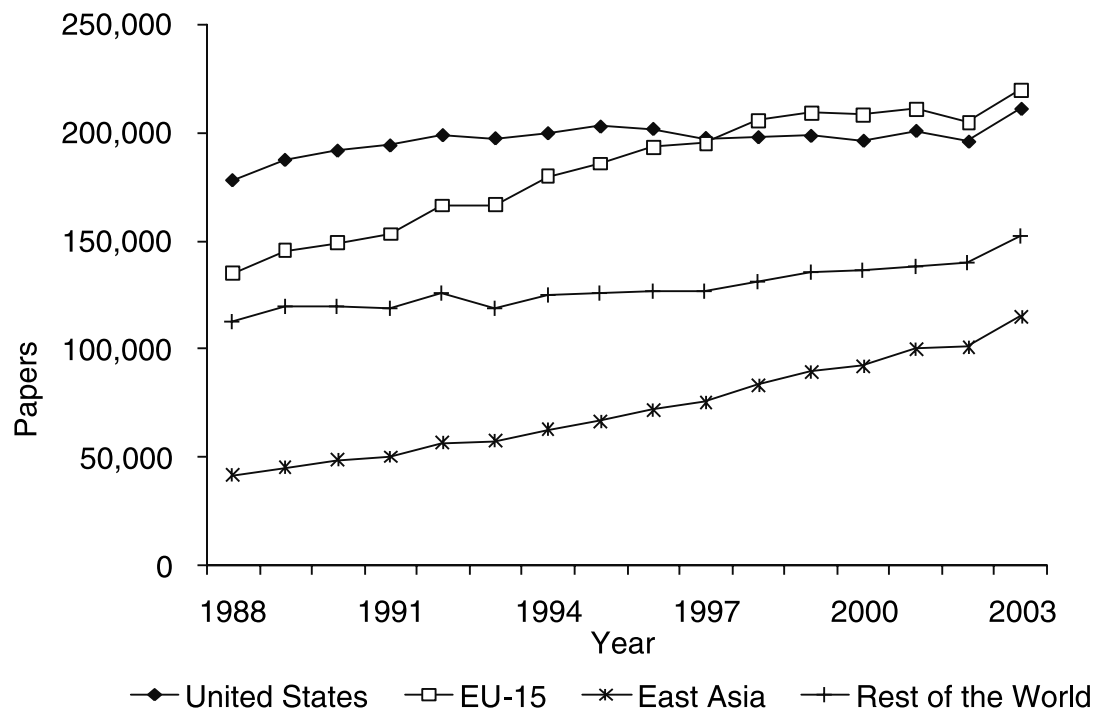

Fig. 1.5 Scientific papers by region, 1988-2003

Source: National Science Board (2006, chapter 5, appendix table 41).

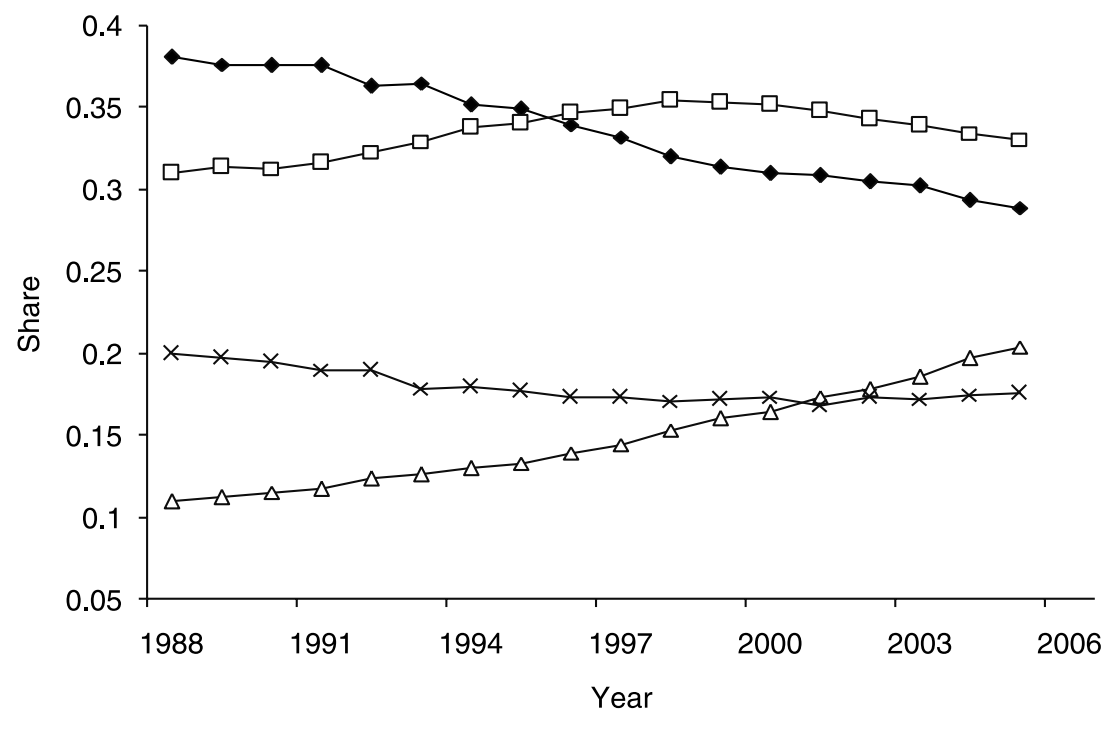

Fig. 1.6 Shares in world scientific papers, 1988-2005

Sources: National Science Board (2006, chapter 5, appendix table 41); National Science Board (2008, chapter 5, appendix table 34). 


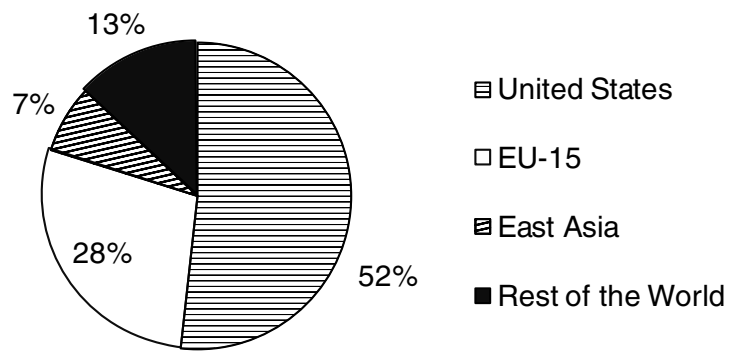

Fig. 1.7 Citation shares by region, 1992

Source: National Science Board (2008, chapter 5, appendix table 61).

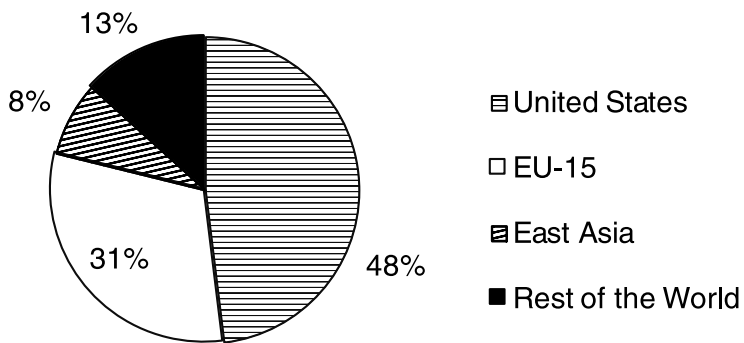

Fig. 1.8 Citation shares by region, 1997

Source: National Science Board (2008, chapter 5, appendix table 61).

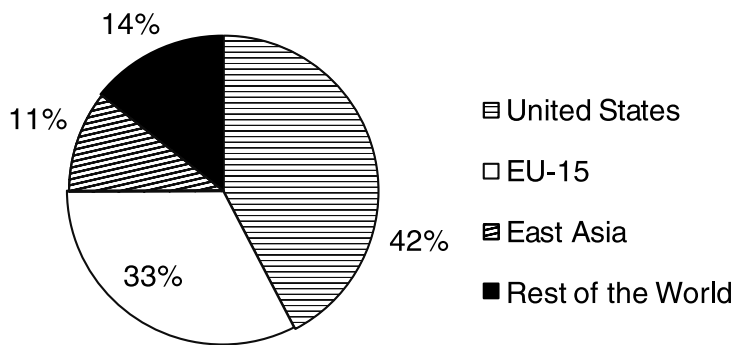

Fig. 1.9 Citation shares by region, 2003

Source: National Science Board (2008, chapter 5, appendix table 61).

fastest. At the end of the period, because of gains in Europe, 75 percent of citations are still received by America and Europe compared with 70 percent at the start.

Figure 1.10 depicts the US share in the top 1 percent, top 5 percent, and top 10 percent most cited papers from 1992 to $2005 .{ }^{26}$ The share erodes at every level, and though it is hard to see, the percentage decline is less for top 1 percent papers than top 5 percent papers. The top 1 percent share declines

26. The data source is appendix table 63, chapter 5, National Science Board (2008). 


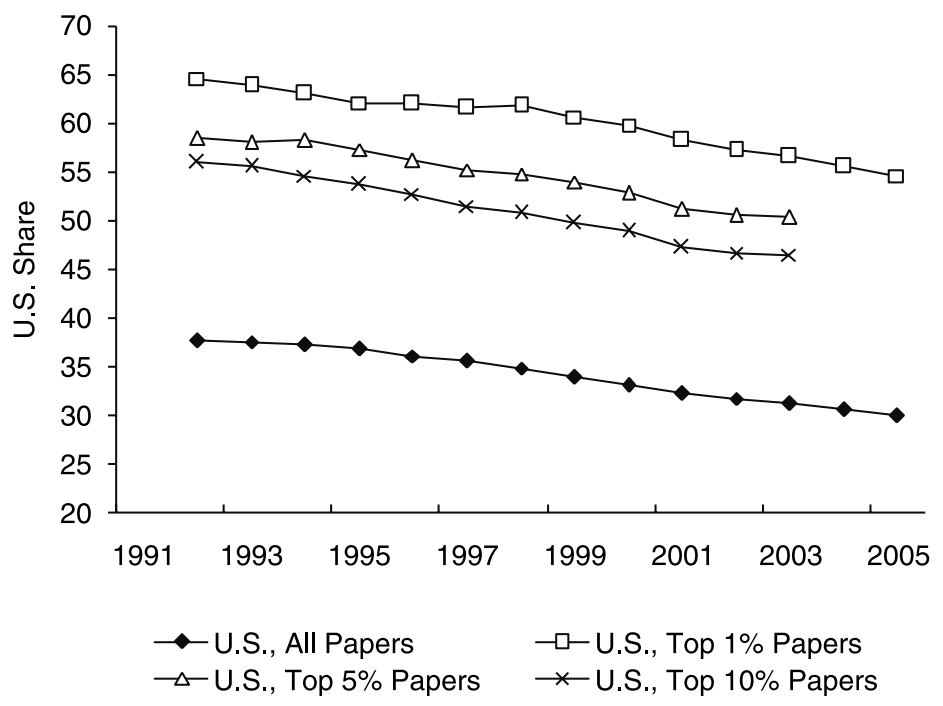

Fig. 1.10 US share in world output of highly cited papers, 1992-2005

Source: National Science Board (2008, chapter 5, appendix table 63).

from 65 percent of the world total in 1992 to 55 percent in 2005. This is a decline of 15 percentage points (10/65). The top 5 percent share declines from 38 percent to 30 percent, a decline of 21 percentage points. So erosion in share is less at higher levels of citation impact, though some may see this as cold comfort.

But what does all this mean? Share data tell us little about welfare. Output adjusted for quality, and output relative to input, are what matter for growth and technical efficiency of an industry, and universities are no exception to this rule. All we can say is that the growth rate of US scientific publications has fallen and that growth is slow relative to other regions, but we have not addressed the factors that drive this slowdown.

Foreign competition for science and engineering students is unlikely to be responsible. ${ }^{27}$ If that were the reason, then the skill of foreign science and engineering graduate students entering US universities would have undergone serious decline in recent years. But this seems implausible given the attractiveness of US education and employment. Alternatively, the slow-

27. In the long run, arguments concerning the diffusion of science and R\&D vary in their implications for welfare of advanced countries like the United States. If technology converges in science and in industrial research then the share of innovative products produced in advanced countries will decline. Standard models build on the theory of trade with differentiated products (Helpman and Krugman 1986). North-South models of innovation, imitation, and trade based on this approach (Krugman 1979; Grossman and Helpman 1991) assume that all innovation occurs in the North, while the South merely imitates. But if advanced human resources arise in the South as well, then innovation is distributed across both North and South, as Freeman (2006) points out. In that case the profits from new products are also distributed across both 
down could represent crowding out of US authors in top journals (Hicks 2007), or diversion to commercial activities (Toole and Czarnitski 2007), or earmarking to less efficient institutions (De Figueiredo and Silverman 2006).

The recent slowdown could derive from other domestic causes and this is the approach that I am about to pursue. I show in section 1.5 that growth of scientific publication in US private universities did not slow down much in the 1990s compared with the 1980s. In contrast, a pronounced deceleration did occur in public universities. In explaining the difference, a deceleration in resource growth during the 1990s seems to be the most likely explanation for the slowdown in public universities. I explore this hypothesis in sections 1.5 and 1.6 .

\subsection{Panel Data on US Universities}

\subsubsection{Data Construction}

With the goal of explaining the slowdown in US academic research, I turn to empirical work using a panel of 110 top US universities. I begin by describing the data. In their raw form they consist of 2.4 million scientific papers, published during 1981 to 1999, that have at least one author from a top 110 US university. These universities account for more than 80 percent of US academic research during this period. ${ }^{28}$

Papers consist of articles, reviews, notes, and proceedings. The data source is Thomson-Reuters Scientific. ${ }^{29}$ Papers follow the field that Thomson assigns to the journal in which they appear. ${ }^{30}$ "Field," in this case, is one of eighty-eight subfields. To link the data to the National Science Foundation's

regions and the North can lose some industries with supra-normal profits. Applying this line of reasoning to universities as an industry suggests that the United States could lose the lead in some sciences, which in turn might contribute to less effective industrial research in the United States. But countervailing forces also apply if product varieties grow with the world economy. First, knowledge flows to industries in advanced countries will increase, including universities, so that scientific discoveries and inventions of new products could increase. Second, the larger world economy that results from the South's entry into advanced nation status would create markets for the North, including in scientific research. So it is not clear whether the North gains or loses as a result of the South's development.

28. According to National Science Board (2002), appendix table 5-4, in 1999 the top 100 US universities account for $\$ 22.10$ billion of R\&D out of $\$ 27.49$ billion of R\&D for all US universities. This equals 80.4 percent. National Science Board (2008), appendix table 5-11 indicates that in 2006 the top 100 account for $\$ 38.09$ billion out of $\$ 47.76$ billion for all US universities. This equals 79.8 percent. Since the sample consists of the top 110 and not the top 100 , its share in $R \& D$ expenditures exceeds 80 percent. Publication data reflect $R \& D$ spending, so the publication share also exceeds 80 percent.

29 . The journal set consists of approximately 5,500 journals that were active in 1999 , as well as 1,600 inactive (renamed or out of print) journals that were cited by active journals.

30. This assignment is reasonable for specialized journals because of the breadth of fields that I use. But the method produces serious errors for the 1 percent of journals (about 70) that fall into Thomson-Reuters's Multidisciplinary category. Thomson treats this category as part 
(NSF) Computer-Aided Science Policy Analysis and Research (CASPAR) database, I assign each of the eighty-eight to one of NSF's twelve main fields. ${ }^{31}$

The data record publication year, journal field, institutional affiliation, address information on city, state, and country, and author names, as well as number of authors. ${ }^{32}$ Address information is used to identify university affiliations of those who collaborate on a paper and to compute fractional papers. By fractional, I mean that if a paper is written by researchers in two universities, then each university is assigned half the paper. If three collaborate, then each receives a third, and so on. ${ }^{33}$ I add up fractional papers by university, field, and year to form "effective" papers produced in a universityfield. By treating the data in this way I avoid multiple counting of papers of US universities taken as a whole. Likewise I compute (forward) citations received by a paper in its first five years, including year of publication, and I calculate fractional five-year citations in the same manner as for papers, but excluding citations from the same institution. I accumulate fractional citations by university, field, and year to form an estimate of "effective" citation-weighted papers in a university-field. ${ }^{34}$

These steps yield research "output" in a university, field, and year. Following along these lines I form a panel of universities, fields, and years. The panel combines papers and citations with university-field level R\&D, university-field $\mathrm{PhD}$ students and post-doctoral students, and characteristics of doctoral programs; as well as financial characteristics of parent universities. The measure used for $\mathrm{R} \& \mathrm{D}$ is a calculated depreciated stock based on past R\&D expenditures. The NSF-CASPAR database of universities, a compendium of NSF surveys, is the source for university R\&D and for graduate and post-graduate students. The HEGIS (Higher Education General Information Surveys) surveys of the US Department of Education provide financial data at the university level on tuition revenues, state appro-

of biology because biology accounts for the largest number of its papers. Multidisciplinary journals include Nature, Science, Proceedings of the National Academy of Sciences USA, and Philosophical Transactions of the Royal Society. Wholesale assignment to biology here is clearly wrong. But to correct the problem would require article (not journal) assignments to fields. Also, some Multidisciplinary journals are primarily focused on biology. Therefore, the problem applies to less than 1 percent of the journals.

31. The twelve fields are: agriculture, astronomy, biology, chemistry, computer science, earth sciences, economics and business, engineering, mathematics and statistics, medicine, physics, and psychology.

32. There is no limit on the number of authors. The maximum number in the sample is 210 , while the mean is 2.36 .

33. The cumulative distribution of universities listed on papers is: one university, 79.6 percent; two universities or less, 96.8 percent; three universities or less, 98.3 percent; and four universities or less, 99.5 percent. It follows that the fractions assigned are almost always $1,1 / 2$, $1 / 3$, or $1 / 4$.

34. It is tempting to think of university-fields as departments, but this is misleading. The same field can be practiced by more than one department and (rarely) multiple fields can be practiced within one department. 
priations (for public universities), endowments, auxiliary revenues from fees, and total revenues. The National Research Council (NRC) 1993 Survey of Doctoral Programs (NRC 1995) includes rankings of $\mathrm{PhD}$ programs, and I use these to stratify departments by relative standing. ${ }^{35}$

In the basic panel of universities I consider only leading university-fields ("departments") from the top 110. Their number depends on size of field: I include the top twenty-five universities in astronomy, the top fifty in agriculture, chemistry, computer science, economics and business, earth sciences, mathematics and statistics, physics, and psychology, and the top seventy-five in biology, medicine, and engineering. Summing across fields, and accounting for the fact that forty-eight formal schools of agriculture exist, the panel consists of 648 top university-fields. My purpose in breaking out few individual schools in small fields and more in large fields is to avoid empty cells for universities where fields are small or nonexistent. ${ }^{36}$ The result is a panel that contains papers and citation-weighted papers for 648 university-fields in twelve main sciences during 1981 to 1999 . This implies a total of 12,312 observations before exclusions due to missing values. In some cases I stratify the data into top 20 percent, middle 40 percent, and bottom 40 percent university-fields. A field that contains fifty university-fields has ten in the top 20 percent, twenty in the middle percent, and twenty in the bottom 40 percent, and so on. The university-field dimension allows for greater variability of R\&D stock, graduate students, and other variables within a university. It increases the robustness of the findings when university dummies are included. The price of this detail is that lagged faculty counts must be replaced by lagged R\&D stocks and a moving average of graduate students. These are the primary indicators of resources that are available at the university, field, and year level.

\subsubsection{Descriptive Statistics}

Table 1.3 contains descriptive statistics for major variables. The table reports means, standard deviations, minima, and maxima. Groups consist of "all," "private," and "public" universities. The last two are the groups used in the rest of the empirical work.

I begin with research output. Mean (fractional) papers in all universities are 177 per university-field and year. They are slightly larger in private schools. The data indicate considerable variation, especially among private schools. The field with the most papers is in a private university. The mean of five-year (fractional) citations received (citation-weighted papers) is 520

35. The NRC ranks are not available for agriculture and medicine. For these fields I sort universities by their $1998 \mathrm{R} \& \mathrm{D}$ and assign a rank of 1 to the university with the largest R\&D and so on in descending order.

36. The size of the remainder of the top 110 equals an average university-field in the individual top twenty-five, fifty, or seventy-five schools. This reflects the positive skew of academic R\&D. For more on this point see Adams and Griliches (1998). 


\begin{tabular}{|c|c|c|c|c|c|}
\hline Variable & Analytical level & Mean & $\begin{array}{l}\text { Standard } \\
\text { deviation }\end{array}$ & Min & $\operatorname{Max}$ \\
\hline \multicolumn{6}{|l|}{ Papers $^{\mathrm{a}}$} \\
\hline All universities & \multirow[t]{3}{*}{ University-field } & 176.8 & 210.9 & 0.5 & $2,559.1$ \\
\hline Private & & 183.1 & 256.2 & 1.3 & $2,559.1$ \\
\hline Public & & 173.6 & 183.2 & 0.5 & $1,317.6$ \\
\hline \multicolumn{6}{|c|}{ Five-year citations received ${ }^{a}$} \\
\hline All universities & \multirow[t]{3}{*}{ University-field } & 520.1 & $1,078.9$ & 0 & $21,954.2$ \\
\hline Private & & 693.8 & $1,518.7$ & 0.9 & $21,954.2$ \\
\hline Public & & 430.8 & 743.4 & 0 & $7,710.8$ \\
\hline \multicolumn{6}{|l|}{ Number of faculty ${ }^{b}$} \\
\hline All universities & \multirow[t]{3}{*}{ University } & $1,236.3$ & 614.6 & 42 & 3,083 \\
\hline Private & & 802.1 & 371.6 & 179 & 2,461 \\
\hline Public & & $1,459.9$ & 595.0 & 42 & 3,083 \\
\hline \multicolumn{6}{|c|}{ Stock of R\&D (millions of 1992 US\$) ${ }^{c}$} \\
\hline All universities & \multirow[t]{3}{*}{ University-field } & 83.3 & 112.7 & 0.0 & $1,441.1$ \\
\hline Private & & 83.4 & 116.6 & 0.0 & 828.9 \\
\hline Public & & 83.3 & 110.6 & 0.2 & $1,441.1$ \\
\hline \multicolumn{6}{|c|}{ Tuition revenues (millions of 1992 US\$) ${ }^{d}$} \\
\hline All universities & \multirow[t]{3}{*}{ University } & 120.4 & 83.9 & 0.7 & 547.4 \\
\hline Private & & 158.1 & 94.7 & 13.0 & 547.4 \\
\hline Public & & 101.0 & 70.2 & 0.7 & 413.0 \\
\hline \multicolumn{6}{|c|}{ State appropriations (millions of 1992 US\$) ${ }^{d}$} \\
\hline All universities & \multirow[t]{3}{*}{ University } & 155.9 & 132.0 & 0 & 489.7 \\
\hline Private & & 11.1 & 30.6 & 0 & 160.8 \\
\hline Public & & 230.5 & 97.8 & 23.9 & 489.7 \\
\hline \multicolumn{6}{|c|}{ Endowment (millions of 1992 US\$) ${ }^{\mathrm{d}}$} \\
\hline All universities & \multirow[t]{3}{*}{ University } & 553.9 & 890.7 & 0.013 & $6,553.7$ \\
\hline Private & & $1,118.9$ & $1,029.4$ & 55.3 & $6,553.7$ \\
\hline Public & & 258.7 & 632.7 & 0.013 & $5,089.6$ \\
\hline \multicolumn{6}{|l|}{ Graduate students $s^{e}$} \\
\hline All universities & \multirow[t]{3}{*}{ University-field } & 258.7 & 343.1 & 0.0 & $4,904.0$ \\
\hline Private & & 198.3 & 363.1 & 0.0 & $4,904.0$ \\
\hline Public & & 289.8 & 328.1 & 0.0 & $2,705.0$ \\
\hline \multicolumn{6}{|c|}{ Auxiliary/total revenues ${ }^{\mathrm{d}}$} \\
\hline All universities & \multirow[t]{3}{*}{ University } & 0.096 & 0.045 & 0.006 & 0.302 \\
\hline Private & & 0.077 & 0.040 & 0.006 & 0.245 \\
\hline Public & & 0.105 & 0.045 & 0.007 & 0.302 \\
\hline \multicolumn{6}{|l|}{ Enrollment/faculty ${ }^{\mathrm{f}}$} \\
\hline All universities & \multirow[t]{3}{*}{ University } & 21.5 & 6.4 & 4.8 & 40.1 \\
\hline Private & & 16.4 & 4.9 & 6.5 & 28.9 \\
\hline Public & & 24.1 & 5.4 & 4.8 & 40.1 \\
\hline
\end{tabular}

Notes: Period is 1982 to 1999. Sources of the data are described in the text and include: Thomson-Reuters Scientific, the CASPAR database of the National Science Foundation, and the HEGIS database of the National Center for Education Statistics.

aPapers and citations received are fractionally assigned to universities in the manner described in the text.

${ }^{\mathrm{b}}$ The number of faculty is the number of tenure-track plus nontenure-track faculty. These data derive from HEGIS.

${ }^{c}$ The stock of R\&D is defined at the university-field level. It derives from the NSF-CASPAR database of universities. ${ }^{\mathrm{d}}$ All the financial variables derive from HEGIS.

${ }^{\text {e}}$ The number of lagged graduate students is for a university-field. It is an average over the previous three years. These data derive from the NSF-CASPAR database of universities.

${ }^{\mathrm{f}}$ The enrollment data derive from HEGIS. 
per university, field, and year. This is 33 percent higher in private schools and 17 percent lower in public schools. Again the maximum occurs in a private university.

For comparison I report faculty counts. Since these exist only at the university level they indicate total research labor. ${ }^{37}$ The average school employs slightly more than 1,200 faculty, private schools employ 800 , and public schools employ 1,500. A smaller faculty in private schools produces the same papers per university-field, but appreciably more citation-weighted papers, than do faculty in public schools. Note that I compare total faculty in universities with papers and citations at the university-field level. But this comparison is also valid at the university level (Adams and Clemmons 2009).

Research \& Development stock signifies lagged resources that enter into research. It is the depreciated sum of total $R \& D$ from federal and other sources in a university-field over the previous eight years. ${ }^{38}$ The depreciation rate is 15 percent; underlying $R \& D$ flows are expressed in millions of 1992 dollars using the Bureau of Economic Analysis (BEA) university R\&D deflator (Robbins and Moylan 2007). The R\&D stock in field $i$, university $j$, at time $t$, is

$$
\mathrm{R} \mathrm{D} \text { Stock }_{i j t}=\sum_{\tau=1}^{8}(0.85)^{\tau} r_{i j, t-\tau} .
$$

Mean R\&D stock is about $\$ 80$ million. Research output varies more than $\mathrm{R} \& \mathrm{D}$, and private universities produce more research than expected, given their R\&D stocks, suggesting that other, less readily observed resources are greater in these universities.

Financial statistics of tuition, state appropriations, and endowment derive from HEGIS. These are expressed in millions of 1992 dollars using the implicit gross domestic product (GDP) deflator. The data are at the university level. ${ }^{39}$ Financial resources could be used to support more and better faculty. For example, tuition in private universities is used to cover start-up packages for assistant professors in science and engineering (Ehrenberg, Rizzo, and Jakubson 2007). Not surprisingly, and despite smaller enrollments, private schools have larger tuition revenues and larger (nontax) endowments. State appropriations capture the "tax endowment" of public universities. I construct the following measure of current revenue in university $j$ :

37. The data include untenured as well as tenure track faculty. In the top 110 about 90 percent are tenure track according to HEGIS. Note that data on faculty by university and field have not been collected since 1985 .

38. I chose an eight-year lagged stock because the NSF CASPAR R\&D data begin in 1973 and papers begin in 1981. It is therefore the maximum length of stock that is available given the data.

39. One difficulty with the financial variables is that they are not available for the late 1990s. This causes an appreciable loss of data as we shall see. 
(2) Revenue $_{j, t}=$ Tuition $_{j, t-1}+$ Public $*$ State Appropriations $_{j, t-1}$.

In equation (2) "public" is a dummy indicator equal to one in public universities and zero otherwise so that in private universities revenue is tuition, since "public" equals zero. But in public universities it is tuition plus state appropriations on the assumption that appropriations substitute for tuition in public universities. I lack a history of revenue, but I lag equation (2) by one year in the research output equations to approximate lagged resources. I treat endowment separately from revenue, since it is a stock, and since it may be earmarked for different uses. Note that I use the endowment stock because endowment income is poorly measured in HEGIS.

The moving average of the stock of graduate students over the previous three years captures numbers of research assistants:

$$
\text { Graduate Students } \mathrm{s}_{i, t}=0.333 * \sum_{\tau=1}^{3} \text { Students }_{i j, t-\tau} .
$$

Table 1.3 shows that public universities employ more graduate students. But numbers of undergraduates are also larger, requiring more of the graduate students to serve as teaching assistants. Besides this, large public university programs in engineering include masters as well as $\mathrm{PhD}$ students. For these reasons, equation (3) is likely to be a noisy indicator of research assistance, and yet it is the best measure that I have.

I use the ratio of auxiliary/total revenues (from HEGIS) to indicate financial duress. Auxiliary revenues are fee-for-service charges for residence halls, food services, athletics, student unions, stores, and movie theaters. ${ }^{40} \mathrm{I}$ divide auxiliary by total revenues to abstract from size of university. The mean of this ratio is 0.10 , although it ranges from zero to 0.30 .

To motivate the use of auxiliary/total revenues, suppose that tuition is price-controlled in a public university. This could occur in states that guarantee tuition to families of students, since the states must then cover tuition if the price cap were to be lifted (Rizzo 2006). If fees were increased in small amounts, then they might substitute for tuition in this setting. Likewise, private universities with small endowments and gifts could use fees to finance their operations. Fees in this interpretation resemble hidden prices for university attendance.

Table 1.4 reports correlations among auxiliary/total revenue, enrollment/ faculty, tuition plus state appropriations per student, and endowment per student. The enrollment/faculty ratio, or the student-teacher ratio, is positively correlated with auxiliary/total revenue. Since an increase in the student-teacher ratio spreads limited resources over more students, it also may indicate financial duress. ${ }^{41}$ Tuition plus state appropriations per student

40. Hospital revenues are separate from auxiliary revenues.

41. An alternative view is that a higher student-teacher ratio automatically increases the share of auxiliary fees. It is by no means perfect as an indicator of financial duress. 
Table 1.4

Correlations among financial indicators

\begin{tabular}{|c|c|c|c|c|}
\hline & $\begin{array}{l}\text { Auxiliary/ } \\
\text { total revenue }\end{array}$ & $\begin{array}{l}\text { Enrollment/ } \\
\text { faculty }\end{array}$ & $\begin{array}{l}\text { Tuition }+ \text { state } \\
\text { appropriations/ } \\
\text { student }\end{array}$ & $\begin{array}{c}\text { Endowment/ } \\
\text { student }\end{array}$ \\
\hline Auxiliary/total revenue & 1.00 & & & \\
\hline Enrollment/faculty & $\begin{aligned} & 0.17 \\
(< & 0.0001)\end{aligned}$ & 1.00 & & \\
\hline $\begin{array}{l}\text { Tuition }+ \text { state } \\
\text { appropriations/student }\end{array}$ & $\begin{array}{c}-0.41 \\
(<0.0001)\end{array}$ & $\begin{aligned} &-0.50 \\
&(<0.0001)\end{aligned}$ & 1.00 & \\
\hline Endowment/student & $\begin{array}{c}-0.25 \\
(<0.0001)\end{array}$ & $\begin{array}{c}-0.35 \\
(<0.0001)\end{array}$ & $\begin{aligned} & 0.21 \\
&(<0.0001)\end{aligned}$ & 1.00 \\
\hline
\end{tabular}

Notes: See text and table 1.3 for data sources and definitions of the financial indicators. (Significance levels in parentheses).

and endowment per student capture more abundant resources per student. They are the opposite of financial duress (Ehrenberg 2002). They should be, and are, negatively correlated with the financial duress indicators, which in this study are auxiliary/total revenue and enrollment/faculty.

\subsection{Growth of University Research}

I now use the university panel data described in section 1.4 to provide an overview of the growth of university research. Understanding these facts is helpful in interpreting the regression analysis of university research in section 1.6. To this end, I have composed three summary tables that are designed to facilitate discussion of trends in university research productivity and the US slowdown in publication rates during the 1990s.

Table 1.5 presents totals of papers, citation-weighted papers, $\mathrm{PhD}$ degrees awarded, and R\&D stock in private and public universities. The data consist of 620 university-fields (out of 648 possible), observed over 1982 to 1999, for which there are no missing values. To aid in the interpretation, I report values relative to 1982 in square brackets. In brief, the data tell us that the output of papers grows by slightly more (slightly less) than 50 percent in private (public) universities; that citations grow by 125 percent in both groups (from 1982 to 1995); and that PhDs grow by a third in both. Since citations rise with the growing ease of citation and with the number of researchers who cite, citation growth is best regarded as an upper bound on the growth of research output. But since papers have genuinely become more influential, growth of papers is a lower bound. Therefore, growth of research output lies between 50 and 125 percent.

This provides a broad range of growth in research output, but what about input? I start by examining the behavior of R\&D stock deflated by the implicit GDP deflator. This grows by 105 percent (130 percent) in private 
Table 1.5

Scientific papers, PhDs, and R\&D stock by university type, selected years

\begin{tabular}{lccccc}
\hline University type, variable & 1982 & 1986 & 1990 & 1995 & 1999 \\
\hline \multirow{2}{*}{ A Private schools } & & & & \\
Papers & 27,591 & 30,776 & 33,342 & 40,022 & 41,952 \\
& {$[1.00]$} & {$[1.12]$} & {$[1.21]$} & {$[1.45]$} & {$[1.52]$} \\
5-year citations & 83,641 & 110,371 & 140,938 & 187,763 & - \\
& {$[1.00]$} & {$[1.32]$} & {$[1.69]$} & {$[2.24]$} & \\
PhD degrees $^{\mathrm{a}}$ & 48,374 & 48,512 & 55,178 & 60,278 & 63,840 \\
& {$[1.00]$} & {$[1.00]$} & {$[1.14]$} & {$[1.25]$} & {$[1.32]$} \\
R\&D stock (mill. of 1992 US\$) & & & & & \\
Using GDP implicit price deflator & 10,296 & 11,709 & 14,641 & 17,775 & 21,099 \\
& {$[1.00]$} & {$[1.14]$} & {$[1.42]$} & {$[1.73]$} & {$[2.05]$} \\
Using BEA university R\&D input deflator & 11,927 & 13,109 & 15,435 & 17,873 & 20,478 \\
& {$[1.00]$} & {$[1.10]$} & {$[1.29]$} & {$[1.50]$} & {$[1.72]$} \\
& B Public schools & & & & \\
Papers & 49,851 & 56,312 & 63,566 & 73,985 & 74,158 \\
& {$[1.00]$} & {$[1.13]$} & {$[1.28]$} & {$[1.48]$} & {$[1.49]$} \\
5-year citations & 101,746 & 125,394 & 173,066 & 229,657 & - \\
PhD degrees & {$[1.00]$} & {$[1.23]$} & {$[1.70]$} & {$[2.26]$} & \\
& 116,709 & 117,402 & 126,311 & 153,026 & 155,505 \\
R\&D stock (mill. of 1992 US\$) & {$[1.00]$} & {$[1.01]$} & {$[1.08]$} & {$[1.31]$} & {$[1.33]$} \\
Using GDP implicit price deflator & 18,400 & 21,771 & 27,963 & 36,385 & 42,257 \\
& {$[1.00]$} & {$[1.18]$} & {$[1.52]$} & {$[1.98]$} & {$[2.30]$} \\
Using BEA university R\&D input deflator & 21,312 & 24,366 & 29,468 & 36,567 & 41,030 \\
& {$[1.00]$} & {$[1.14]$} & {$[1.38]$} & {$[1.72]$} & {$[1.93]$} \\
\hline
\end{tabular}

Notes: Value relative to 1982 in brackets. See the text and table 1.3 for data sources and definitions of the variables. Data are a balanced panel of university-fields, defined as a matched sample that includes the same observations in all years. The sample includes all the data. Papers and five-year citations received are fractional and are adjusted for collaboration among universities. Dashed cells indicate that data are not available for the data set.

${ }^{\text {a }} \mathrm{PhD}$ degrees are specific to university-fields and belong to twelve main fields of science and engineering: agriculture, astronomy, biology, chemistry, computer science, earth science, economics and business, engineering, mathematics and statistics, medicine, physics, and psychology.

${ }^{b} \mathrm{R} \& \mathrm{D}$ stock is deflated by the GDP implicit price deflator in the first row, and by the BEA University R\&D input deflator (Robbins and Moylan 2007) in the second row. Both price indexes are normalized to 1992.

(public) schools. The R\&D growth exceeds publication and $\mathrm{PhD}$ growth: surely, one supposes, this is a recipe for a slowdown in research productivity. But R\&D growth is overstated, because the GDP deflator understates cost increases in universities and overstates growth of real R\&D. The evidence in table 1.12, on rising real compensation of faculty, helps to make this clear.

For this reason I prefer the BEA price index for university R\&D (Robbins and Moylan 2007), because it takes university wage costs into account, and I use the BEA index to deflate R\&D stock in all the regressions to follow. When I use the BEA index instead of the implicit GDP deflator to calculate real $R \& D$, I find that $R \& D$ in private universities grows by 72 percent, not 
105 percent. Likewise I find that growth in public schools is 93 percent, not 130 percent. Using the improved deflator, real R\&D grows by 70 (90) percent in private (public) universities, while research output grows by 50/125 percent in both. In this way the gap narrows between growth of articles and growth of real R\&D.

Even so, growth of real R\&D is likely to be overstated despite the use of the BEA deflator. First, interuniversity grants probably grow in importance during this time because of large projects in biology and other fields. Since grants are not apportioned among schools in the statistics until well after 1999, R\&D is increasingly overcounted because of this. Second, an increasing amount of funding could be targeted for training of graduate students rather than faculty research. To assess research productivity with more accuracy it would be useful to separate funds for research from funds for pure training. A related point might be important, if universities move from institutional to grant support of graduate students. To that extent, grants replace internal funds and they are not additional funds for research. I mention these problems not because I have solutions to them but in the interest of producing better statistics on university R\&D in the future.

Table 1.5 shows that publications in private universities grow more slowly than R\&D stock. The same point applies even more strongly to public universities. While growth of papers slows down during 1995 to 1999 in private universities, it virtually stops in public universities. However, the growth rate of papers recovers somewhat during 2000 to 2005 (see figure 1.5) so this slowdown is to some extent temporary. ${ }^{42}$

Table 1.6 constructs ratios of papers, citations, and $\mathrm{PhD}$ students to $\mathrm{R} \& \mathrm{D}$ stocks using the GDP and BEA deflators, and it examines their growth. Using the BEA deflator, papers per million dollars decline over time in private schools by -11 percent, but the decline is -23 percent in public universities. Citations per million also grow significantly faster in private universities. In comparing research productivity, it is useful to remember that faculty compensation rises by almost 1 percent faster a year in private universities. Almost paradoxically, this may explain why papers (citations) per million dollars of $\mathrm{R} \& \mathrm{D}$ fall less (rise more). It is because labor quality grows at a faster rate in private universities due to faster wage growth in these universities. Finally, $\mathrm{PhD}$ students per million dollars decline by 50 percent in both types of university.

Table 1.7 takes a different look at university resources. It records enrollment, tenure track and non-tenure track faculty, and tuition (in public universities, tuition plus state appropriations). All variables are at the university level. Values relative to 1982 are again placed in square brackets. These

42. For all academic institutions, total scientific papers published fell from 139,168 in 1995 to 138,472 in 1999 . But by 2005 this total had increased to 159,972 . Numbers of scientific papers reflect year of entry into the database rather than year of publication. See National Science Board (2008, chapter 5, appendix table 5-36). 
Research output/R\&D stock by university type, selected years

\begin{tabular}{lccccc}
\hline University type, variable & 1982 & 1986 & 1990 & 1995 & 1999 \\
\hline & A Private schools & & & & \\
Papers/R\&D stock & & & & & \\
$\quad$ Using GDP implicit price deflator & 2.68 & 2.63 & 2.28 & 2.25 & 1.99 \\
$\quad$ Using BEA university R\&D input deflator & 2.31 & 2.35 & 2.16 & 2.24 & 2.05 \\
5-year citations/R\&D stock & & & & & \\
$\quad$ Using GDP implicit price deflator & 8.12 & 9.43 & 9.63 & 10.56 & - \\
$\quad$ Using BEA university R\&D input deflator & 7.01 & 8.42 & 9.13 & 10.51 & - \\
PhD degrees/R\&D stock & & & & & \\
$\quad$ Using GDP implicit price deflator & 4.70 & 4.14 & 3.77 & 3.39 & 3.03 \\
$\quad$ Using BEA university R\&D input deflator & 4.06 & 3.70 & 3.57 & 3.37 & 3.12 \\
$\quad$ B Public schools & & & & \\
Papers/R\&D stock & & & & & \\
$\quad$ Using GDP implicit price deflator & 2.71 & 2.59 & 2.27 & 2.03 & 1.75 \\
$\quad$ Using BEA university R\&D input deflator & 2.34 & 2.31 & 2.16 & 2.02 & 1.81 \\
5-year citations/R\&D stock & & & & & \\
$\quad$ Using GDP implicit price deflator & 5.53 & 5.76 & 6.19 & 6.31 & - \\
$\quad$ Using BEA university R\&D input deflator & 4.77 & 5.15 & 5.87 & 6.28 & - \\
PhD degrees/R\&D stock & & & & & \\
$\quad$ Using GDP implicit price deflator & 6.34 & 5.39 & 4.52 & 4.21 & 3.68 \\
$\quad$ Using BEA university R\&D input deflator & 5.48 & 4.82 & 4.29 & 4.18 & 3.79 \\
\hline
\end{tabular}

Notes: See the text and table 1.3 for data sources and definitions of the variables. Data are a balanced panel of university-fields, defined as a matched sample that includes the same observations in all years. Papers and 5-year citations received are fractional and adjusted for collaboration among universities. R\&D stock is deflated by the GDP implicit price deflator in the first row for each of the variables, and by the BEA University R\&D input deflator (Robbins and Moylan 2007) in the second row. Both price indexes are normalized to 1992. Dashed cells indicate that data are not available for the data set.

measures track teaching loads as well as human and financial resources over time.

Growth in enrollments in both private and public institutions is about 10 percent by 1997 . Since PhD degrees increase by one-third, enrollment shifts toward (more costly) graduate education. Numbers of faculty grow by 25 percent in private universities, but by 8 percent in public universities. Most of the growth in private universities occurs at the end, during a period of rapid growth in stock market and endowment values. Its effects will be felt in the twenty-first century. Tuition revenue grows by 124 percent in private universities but tuition plus state appropriations in public universities grow by just 46 percent. The divergence in resources becomes obvious during the 1990s. It helps to account for differences in private-public productivity, since we shall show that current revenues support research.

Endowments grow at the same rate in all institutions, though the difference in endowment per faculty remains large. It is 1.39 million in private universities versus 0.15 million in public universities. Endowment is simply too small in most public institutions to affect faculty resources very much. 
Table 1.7

Enrollment, faculty, and financial resources by university type, selected years

\begin{tabular}{|c|c|c|c|c|}
\hline University type, variable & 1982 & 1986 & 1990 & 1997 \\
\hline \multicolumn{5}{|c|}{ A Private schools } \\
\hline \multirow[t]{2}{*}{ Enrollment } & 403,875 & 413,824 & 428,522 & 446,495 \\
\hline & {$[1.00]$} & {$[1.02]$} & {$[1.06]$} & [1.11] \\
\hline \multirow[t]{2}{*}{ Faculty } & 21,527 & 22,352 & 23,246 & 26,960 \\
\hline & {$[1.00]$} & {$[1.04]$} & {$[1.08]$} & {$[1.25]$} \\
\hline \multirow[t]{2}{*}{ Tuition (mill. of 1992 US\$) ${ }^{a}$} & 2,975 & 4,034 & 5,026 & 6,668 \\
\hline & {$[1.00]$} & [1.36] & [1.69] & {$[2.24]$} \\
\hline \multirow[t]{2}{*}{ Endowment (mill. of 1992 US\$) ${ }^{b}$} & 13,768 & 19,531 & 27,645 & 37,361 \\
\hline & {$[1.00]$} & [1.42] & {$[2.01]$} & {$[2.71]$} \\
\hline \multicolumn{5}{|c|}{ B Public schools } \\
\hline \multirow[t]{2}{*}{ Enrollment } & $1,895,564$ & $1,908,438$ & $1,999,802$ & $2,053,056$ \\
\hline & [1.00] & [1.01] & [1.06] & [1.08] \\
\hline \multirow[t]{2}{*}{ Faculty } & 80,112 & 80,458 & 84,448 & 86,158 \\
\hline & {$[1.00]$} & {$[1.00]$} & {$[1.05]$} & [1.08] \\
\hline \multirow{2}{*}{$\begin{array}{l}\text { Tuition + state appropriations (mill. } \\
\text { of } 1992 \text { US\$) })^{\mathrm{a}}\end{array}$} & 14,554 & 17,400 & 19,706 & 21,242 \\
\hline & [1.00] & [1.20] & [1.35] & [1.46] \\
\hline \multirow[t]{2}{*}{ Endowment (mill. of 1992 US\$) $)^{b}$} & 4,524 & 6,879 & 8,309 & 12,619 \\
\hline & {$[1.00]$} & [1.52] & [1.84] & [2.79] \\
\hline
\end{tabular}

Notes: Value relative to 1982 in brackets. See the text and table 1.3 for data sources and definitions of the variables. Data are a balanced panel, defined as a matched sample that includes the same observations in all years. Enrollment consists of all students, both graduate and undergraduate, in the fall of each year. Faculty include both tenure-track and non-tenuretrack personnel.

aTuition and state appropriations end in 1997 owing to suspension of data collection in the HEGIS surveys beginning in 1998.

${ }^{b}$ Endowment data end in 1996 instead of 1997 owing to suspension of data collection in the HEGIS surveys beginning in 1997. The endowment data are missing for about 20 percent of universities so the matched sample is smaller than for other variables. Deflator for revenue and endowment is the implicit GDP deflator indexed to 1992.

Together, tables 1.5 and 1.7 provide a new perspective on university research productivity. Table 1.5 shows that papers increase by 50 percent during this period, while citation-weighted papers increase by 125 percent. Table 1.7 shows that faculty increase by 10 to 25 percent. Papers per faculty increase by either measure, and this draws attention to the point made earlier, that growth of university R\&D is overstated. At the same time, research productivity in public universities has clearly fallen behind that of the privates.

\subsection{Regression Findings}

\subsubsection{Equation Setup}

To better understand the determinants of research productivity, I turn to a regression analysis of the university, field, and year panel. Tables 1.8 and 
1.9 present pooled ordinary least squares (OLS) regressions for private and public universities. By pooled, I specifically mean regressions that combine fields in a given university. As I have shown, the university-field dimension of the data allows for variability within universities that helps to identify effects of R\&D stock and other variables.

The regressions follow three basic formats that we describe next. Let $y_{i j t}$ be the logarithm of research output (papers or citations) in field $i$, university $j$, at time $t$; let the vector $\mathbf{x}_{\mathrm{ijt}}$ consist of logarithms of R\&D stock, graduate students, and current revenue defined by equations (1), (3), and (2); and let the vector $\mathbf{z}_{\mathrm{jit}}$ stand for financial variables at the university level (endowment in logarithms; auxiliary/total revenue, and enrollment/faculty). Also, $\mathbf{D}_{\mathbf{i}}$ is a vector of field dummies. ${ }^{43}$ Then the "total" equation that omits university dummies is:

$$
y_{i j t}=\alpha+\beta_{0} t+\boldsymbol{\beta}_{\mathbf{x}}^{\prime} \mathbf{x}_{\mathrm{ijt}}+\boldsymbol{\delta}_{\mathbf{i}}^{\prime} \mathbf{D}_{\mathbf{i}}+e_{j}+u_{i j t} .
$$

Financial variables $z_{j t}$ are omitted from equation (4), but they are included in $\left(4^{\prime}\right)$ :

$$
y_{i j t}=\alpha+\beta_{0} t+\boldsymbol{\beta}_{\mathbf{x}}^{\prime} \mathbf{x}_{\mathrm{ijt}}+\boldsymbol{\gamma}_{\mathbf{z}}^{\prime} \mathbf{z}_{\mathbf{j t}}+\boldsymbol{\delta}_{\mathbf{i}}^{\prime} \mathbf{D}_{\mathbf{i}}+e_{j}+u_{i j t} .
$$

In equations (4) and (4'), $e_{j}$ is a university error component that may be correlated with the right-hand variables, while $u_{i j t}$ is a transitory component that is uncorrelated over time both with itself and with the contemporaneous right-hand variables.

The "within" equation adds university dummies to equation (4'):

$$
y_{i j t}=\alpha+\beta_{0} t+\boldsymbol{\beta}_{\mathbf{x}}^{\prime} \mathbf{x}_{\mathrm{ijt}}+\boldsymbol{\gamma}_{\mathbf{z}}^{\prime} \mathbf{z}_{\mathbf{j t}}+\boldsymbol{\delta}_{\mathbf{i}}^{\prime} \mathbf{D}_{\mathbf{i}}+\boldsymbol{\delta}_{\mathbf{j}}^{\prime} \mathbf{D}_{\mathbf{j}}+u_{i j t} .
$$

In equation (5), the vector of university dummies $D_{j}$ absorbs the university error component, so that $e_{j}=\boldsymbol{\delta}_{\mathbf{j}}^{\prime} \mathbf{D}_{\mathbf{j}}{ }^{44}$

I also include time trend in equations (4), (4'), and (5) to indicate residual growth. If trend increases when university effects are included, then this may indicate that research output shifts toward universities where output grows more slowly (Adams and Clemmons 2009).

\subsubsection{Pooled Regressions: Private Universities}

Table 1.8 reports estimates for private universities. Following (4), column (8.1) includes trend, R\&D stock, and the stock of graduate students. All are highly significant, and together they explain most of the variation in papers. ${ }^{45}$ The elasticity of R\&D stock is 0.41 , while that of graduate stu-

43. In other regressions I include shares of full and associate professors to capture aging effects. The shares are insignificant. Unlike individual productivity of scientists (Stephan and Levin 1991, 1992) where age is significantly negative, at the university and field level rank is insignificant. One explanation for the difference is that selective pressures favor more productive researchers. Promotion in the aggregate counteracts individual aging.

44. See Hsiao (2003, chapters 2 and 3) for derivations of estimators of the slope coefficients in total and within regressions.

45. See Adams and Griliches (1998) for a related analysis. 
Table 1.8

Ordinary least squares research regressions: Private universities

\begin{tabular}{lcccccc}
\hline Variable or statistic & \multicolumn{3}{c}{ Log (papers) } & \multicolumn{3}{c}{ Log (5-year citations) } \\
\hline & 8.1 & 8.2 & 8.3 & 8.4 & 8.5 & 8.6 \\
Field dummies included & Yes & Yes & Yes & Yes & Yes & Yes \\
University dummies included & No & No & Yes & No & No & Yes \\
Regression structure & Total & Total & Within & Total & Total & Within \\
Time trend & $0.0102^{* *}$ & -0.0018 & -0.0035 & $0.0333^{* *}$ & 0.0097 & -0.0112 \\
& $(0.0025)$ & $(0.0050)$ & $(0.0087)$ & $(0.0042)$ & $(0.0070)$ & $(0.0121)$ \\
Log (R\&D stock in mill. of & $0.413^{* *}$ & $0.369^{* *}$ & $0.294^{* *}$ & $0.563^{* *}$ & $0.474^{* *}$ & $0.377^{* *}$ \\
1992 US\$) & $(0.045)$ & $(0.039)$ & $(0.036)$ & $(0.059)$ & $(0.052)$ & $(0.043)$ \\
Log (graduate students) & $0.157^{* *}$ & $0.127^{* *}$ & $0.132^{*}$ & 0.092 & 0.083 & 0.088 \\
& $(0.049)$ & $(0.047)$ & $(0.055)$ & $(0.054)$ & $(0.057)$ & $(0.066)$ \\
Log (tuition rev. in mill. of & & 0.137 & $0.270^{*}$ & & 0.186 & $0.624^{* *}$ \\
1992 US\$) & & $(0.086)$ & $(0.129)$ & & $(0.130)$ & $(0.214)$ \\
Log (endowment in mill. of & & $0.102^{*}$ & 0.055 & & $0.205^{* *}$ & $0.196^{* *}$ \\
1992 US\$) & & $(0.050)$ & $(0.071)$ & & $(0.070)$ & $(0.076)$ \\
Auxiliary/total rev. & & -1.912 & $-1.832^{*}$ & & -1.517 & -1.233 \\
& & $(0.985)$ & $(0.796)$ & & $(1.438)$ & $(1.001)$ \\
Enrollment/faculty & & -0.015 & $-0.009^{*}$ & & $-0.029^{*}$ & -0.004 \\
& & $(0.008)$ & $(0.004)$ & & $(0.012)$ & $(0.005)$ \\
Number of observations & 3,255 & 2,636 & 2,636 & 2,523 & 2,454 & 2,454 \\
$R^{2}$ & 0.84 & 0.86 & 0.88 & 0.85 & 0.87 & 0.90 \\
Root MSE & 0.471 & 0.448 & 0.407 & 0.641 & 0.597 & 0.536 \\
\hline
\end{tabular}

Notes: Robust, clustered standard error in parentheses. See the text and table 1.3 for data sources and definitions of the variables. MSE $=$ mean squared error.

***Significant at the 1 percent level.

**Significant at the 5 percent level.

*Significant at the 10 percent level.

dents is 0.16 . It follows that an expansion of $\mathrm{R} \& \mathrm{D}$ and graduate students of 10 percent results in 5.7 percent more papers in private universities, indicating diminishing returns to research resources. Following equation $\left(4^{\prime}\right)$, column (8.2) adds financial variables. Lagged tuition is linked to an increase in papers, but this is not statistically significant. The coefficient of endowment is positive and marginally significant. Auxiliary/total revenue and enrollment/faculty (financial duress) reduce research output, but again are not statistically significant. As in equation (5), column (8.3) adds university dummies. Tuition revenue now enters significantly as do the indicators of financial duress. In columns (8.2) and (8.3), trend becomes insignificant so that growth of research output is fully explained. R\&D stock and graduate students decline slightly, but remain significant.

Columns (8.4) through (8.6) explain five-year citations received. While the elasticity of R\&D stock increases compared to the earlier regressions for papers, that of graduate students declines and becomes insignificant. Endowment is linked to an increase in citations, suggesting that private uni- 
versities use endowment to buy release time and hire star faculty. As with papers, trend is not significant once the financial indicators are included.

In all these production functions and those in succeeding tables, the sum of the output elasticities across R\&D stock, graduate students, tuition revenue, and endowment is less than 1.0. This suggests decreasing returns to scale in university research and limits to university size, consistent with Adams and Clemmons (2009). The relevance of this point is that, allowing for fixed costs of research and after the efficient scale is reached, research may be better shifted to universities in which it was previously missing. We shall return to this point in the summary and conclusion in section 1.7.

\subsubsection{Pooled Regressions: Public Universities}

Table 1.9 reports results for public universities. In general, output elasticities of $\mathrm{R} \& \mathrm{D}$ stock are less than in table 1.8 for private schools. One difference, though, is the larger elasticity of the stock of graduate students,

Table 1.9

Ordinary least squares research regressions: Public universities

\begin{tabular}{|c|c|c|c|c|c|c|}
\hline \multirow[t]{2}{*}{ Variable or statistic } & \multicolumn{3}{|c|}{ Log (papers) } & \multicolumn{3}{|c|}{ Log (5-year citations) } \\
\hline & 9.1 & 9.2 & 9.3 & 9.4 & 9.5 & 9.6 \\
\hline Field dummies included & Yes & Yes & Yes & Yes & Yes & Yes \\
\hline University dummies included & No & No & Yes & No & No & Yes \\
\hline Regression structure & Total & Total & Within & Total & Total & Within \\
\hline Time trend & $\begin{array}{l}0.0115^{* *} \\
(0.0017)\end{array}$ & $\begin{array}{c}0.0023 \\
(0.0026)\end{array}$ & $\begin{array}{l}0.0144^{* *} \\
(0.0018)\end{array}$ & $\begin{array}{l}0.0415^{* *} \\
(0.0031)\end{array}$ & $\begin{array}{l}0.0236^{* *} \\
(0.0049)\end{array}$ & $\begin{array}{l}0.0448^{* *} \\
(0.0028)\end{array}$ \\
\hline $\begin{array}{l}\log (\mathrm{R} \& D \text { stock in mill. of } \\
1992 \text { US\$) }\end{array}$ & $\begin{array}{l}0.341 * * \\
(0.034)\end{array}$ & $\begin{array}{l}0.338 * * \\
(0.034)\end{array}$ & $\begin{array}{l}0.335^{* *} \\
(0.035)\end{array}$ & $\begin{array}{l}0.416^{* *} \\
(0.042)\end{array}$ & $\begin{array}{l}0.406^{* *} \\
(0.041)\end{array}$ & $\begin{array}{l}0.397^{* *} \\
(0.042)\end{array}$ \\
\hline Log (graduate students) & $\begin{array}{l}0.288^{* *} \\
(0.042)\end{array}$ & $\begin{array}{l}0.215^{* *} \\
(0.038)\end{array}$ & $\begin{array}{l}0.173^{* *} \\
(0.041)\end{array}$ & $\begin{array}{l}0.232^{* *} \\
(0.053)\end{array}$ & $\begin{array}{l}0.156^{* *} \\
(0.046)\end{array}$ & $\begin{array}{l}0.127^{* *} \\
(0.046)\end{array}$ \\
\hline $\begin{array}{l}\text { Log (tuition + state } \\
\text { appropriations in mill. of } \\
1992 \text { US\$) }\end{array}$ & & $\begin{array}{l}0.267^{* *} \\
(0.063)\end{array}$ & $\begin{array}{l}0.142^{* *} \\
(0.048)\end{array}$ & & $\begin{array}{l}0.224 * \\
(0.092)\end{array}$ & $\begin{array}{c}0.163 \\
(0.084)\end{array}$ \\
\hline $\begin{array}{l}\text { Log (endowment in mill. of } \\
1992 \text { US\$) }\end{array}$ & & $\begin{array}{c}0.019 \\
(0.011)\end{array}$ & $\begin{array}{l}-0.018 \\
(0.010)\end{array}$ & & $\begin{array}{l}0.050^{* *} \\
(0.018)\end{array}$ & $\begin{array}{l}-0.044 * * \\
(0.018)\end{array}$ \\
\hline Auxiliary/total rev. & & $\begin{array}{l}-1.384^{* *} \\
(0.401)\end{array}$ & $\begin{array}{c}0.124 \\
(0.157)\end{array}$ & & $\begin{array}{c}-2.389 * * \\
(0.634)\end{array}$ & $\begin{array}{c}0.459 \\
(0.349)\end{array}$ \\
\hline Enrollment/faculty & & $\begin{array}{c}-0.009^{*} \\
(0.004)\end{array}$ & $\begin{array}{c}-0.004 * \\
(0.002)\end{array}$ & & $\begin{array}{c}-0.008 \\
(0.006)\end{array}$ & $\begin{array}{c}-0.002 \\
(0.005)\end{array}$ \\
\hline Number of observations & 6,552 & 4,678 & 4,678 & 5,088 & 4,378 & 4,378 \\
\hline$R^{2}$ & 0.84 & 0.86 & 0.90 & 0.83 & 0.85 & 0.89 \\
\hline Root MSE & 0.429 & 0.400 & 0.342 & 0.634 & 0.595 & 0.506 \\
\hline
\end{tabular}

Notes: Robust, clustered standard error in parentheses. See the text and table 1.3 for data sources and definitions of the variables. MSE = mean squared error.

*** Significant at the 1 percent level.

**Significant at the 5 percent level.

*Significant at the 10 percent level. 
about 0.1 higher and significant throughout. This may indicate that graduate student assistants are funded in public universities, to a larger extent, by means other than R\&D, such as teaching assistantships. Research output rises, usually significantly, with tuition plus state appropriations. Endowment does not contribute to research output in public universities, because amounts per faculty member are too small to matter. Auxiliary/total revenues and enrollment/faculty enter with the expected negative signs, but are insignificant once university effects are taken into account.

The trend coefficient is also greater in the public university regressions. The coefficient of trend is even higher in the "within" regressions (columns [9.3] and [9.6]) than in total. Again, this may reflect a shift of research toward schools where output growth is slower (Adams and Clemmons 2009). Some of trend growth could also be due to knowledge flows from private universities, since knowledge flows are more likely to take place from higher to lower ranked departments (Adams, Clemmons, and Stephan 2006) and since top departments are more often found in private universities.

\subsubsection{Regressions Stratified by Rank of University-Field}

Let us now consider university-fields stratified into groups according to top 20 , middle 40 , and bottom 40 percent rankings. Table 1.10 contains frequency distributions of the top 20 , middle 40 , and bottom 40 by private and public ownership. The top 20 and middle 40 percent account for most of the private school observations. In contrast, public school observations cluster in the middle and bottom 40 percent. Even so, public universities contain almost half of the top 20 percent university-fields. The stratified regressions take this into account by analyzing differences in quality wherever they occur.

Table 1.11 reports estimates of equations (4') and (5). It shows results for the top 20, middle 40, and bottom 40 percent in panels A, B, and C, respectively. Because I separate university-fields into groups by rank, the

Table 1.10

Relationship of rank of university-fields to private and public schools

\begin{tabular}{lcccc}
\hline & \multicolumn{4}{c}{ Rank of university-field } \\
\cline { 2 - 5 } University type & Top $20 \%$ & Middle $40 \%$ & Bottom $40 \%$ & All \\
\hline Private & 72 & 90 & 52 & 214 \\
& $(33.6 \%)$ & $(42.1 \%)$ & $(24.3 \%)$ & $(100 \%)$ \\
Public & 56 & 160 & 190 & 406 \\
& $(13.8 \%)$ & $(39.4 \%)$ & $(46.8 \%)$ & $(100 \%)$ \\
\hline
\end{tabular}

Notes: Row percents in parentheses. See the text for data sources and a description of the underlying panel data. Data consist of 620 private and public university-fields from 103 universities after exclusion of missing values. Top ten universities include eight private and two public schools. 


\begin{tabular}{|c|c|c|c|c|}
\hline \multirow[b]{2}{*}{ Variable or statistic } & \multicolumn{2}{|c|}{ Log (papers) } & \multicolumn{2}{|c|}{ Log (5-year citations) } \\
\hline & $\begin{array}{c}\text { Total } \\
\text { regression }\end{array}$ & $\begin{array}{l}\text { Within } \\
\text { regression }\end{array}$ & $\begin{array}{c}\text { Total } \\
\text { regression }\end{array}$ & $\begin{array}{l}\text { Within } \\
\text { regression }\end{array}$ \\
\hline \multicolumn{5}{|c|}{ A Top 20 percent university-fields } \\
\hline Equation no. & 11.1 & 11.2 & 11.3 & 11.4 \\
\hline \multirow[t]{2}{*}{ Time trend } & $0.0089^{*}$ & $0.0119 * *$ & $0.0249^{* *}$ & $0.0158^{*}$ \\
\hline & $(0.0035)$ & $(0.0044)$ & $(0.0050)$ & $(0.0079)$ \\
\hline \multirow[t]{2}{*}{ Log (R\&D stock in mill. of 1992 US\$) } & $0.310^{* *}$ & $0.284 * *$ & $0.278^{* *}$ & $0.270^{* *}$ \\
\hline & $(0.057)$ & $(0.076)$ & $(0.058)$ & $(0.077)$ \\
\hline \multirow[t]{2}{*}{ Log (graduate students) } & $0.157 * *$ & $0.196^{* *}$ & $0.139 * *$ & $0.193^{* *}$ \\
\hline & $(0.049)$ & $(0.062)$ & $(0.052)$ & $(0.075)$ \\
\hline Number of observations & 1,501 & 1,501 & 1,407 & 1,407 \\
\hline$R^{2}$ & 0.89 & 0.91 & 0.91 & 0.92 \\
\hline Root MSE & 0.365 & 0.328 & 0.447 & 0.413 \\
\hline \multicolumn{5}{|c|}{ B Middle 40 percent university-fields } \\
\hline Equation no. & 11.5 & 11.6 & 11.7 & 11.8 \\
\hline \multirow[t]{2}{*}{ Time trend } & $0.0063^{*}$ & $0.0178 * *$ & $0.0337 * *$ & $0.0475^{* *}$ \\
\hline & $(0.0030)$ & $(0.0034)$ & $(0.0046)$ & $(0.0057)$ \\
\hline \multirow[t]{2}{*}{$\log (\mathrm{R} \& \mathrm{D}$ stock in mill. of 1992 US\$) } & $0.297 * *$ & $0.266^{* *}$ & $0.301 * *$ & $0.304 * *$ \\
\hline & $(0.034)$ & $(0.037)$ & $(0.042)$ & $(0.048)$ \\
\hline \multirow[t]{2}{*}{ Log (graduate students) } & $0.151^{* *}$ & $0.135^{* *}$ & 0.075 & 0.043 \\
\hline & $(0.041)$ & $(0.053)$ & $(0.047)$ & $(0.062)$ \\
\hline Number of observations & 3,077 & 3,077 & 2,877 & 2,877 \\
\hline$R^{2}$ & 0.89 & 0.93 & 0.89 & 0.92 \\
\hline Root MSE & 0.349 & 0.283 & 0.492 & 0.420 \\
\hline \multicolumn{5}{|c|}{ C Bottom 40 percent university-fields } \\
\hline Equation no. & 11.9 & 11.10 & 11.11 & 11.12 \\
\hline \multirow[t]{2}{*}{ Time trend } & $0.0114^{*}$ & $0.0231^{* *}$ & $0.0414^{* *}$ & $0.0539 * *$ \\
\hline & $(0.0041)$ & $(0.0030)$ & $(0.0054)$ & $(0.0064)$ \\
\hline \multirow[t]{2}{*}{ Log (R\&D stock in mill. of 1992 US\$) } & $0.222 * *$ & $0.203^{* *}$ & $0.264 * *$ & $0.252^{* *}$ \\
\hline & $(0.044)$ & $(0.038)$ & $(0.049)$ & $(0.051)$ \\
\hline \multirow[t]{2}{*}{ Log (graduate students) } & 0.083 & 0.100 & -0.006 & 0.089 \\
\hline & $(0.051)$ & $(0.057)$ & $(0.055)$ & $(0.069)$ \\
\hline Number of observations & 2,736 & 2,736 & 2,548 & 2,548 \\
\hline$R^{2}$ & 0.81 & 0.87 & 0.84 & 0.89 \\
\hline Root MSE & 0.447 & 0.374 & 0.624 & 0.541 \\
\hline
\end{tabular}

Notes: Robust, clustered standard error in parentheses. See the text and table 1.3 for data sources and definitions of the variables. Top 20, middle 40 , and bottom 40 percent groups are ranked according to field using 1993 NRC rankings, except for agriculture and medicine, where, because of missing data, university-fields are ranked by size of R\&D expenditure. All regressions include field dummies. Total regressions exclude university dummies while within-regressions include them. Also included are Log (tuition + public * state appropriations), Log (endowment), auxiliary/total revenue, and enrollment/ faculty. MSE = mean squared error.

***Significant at the 1 percent level.

**Significant at the 5 percent level.

*Significant at the 10 percent level. 
regressions are stratified, though they are pooled across fields. ${ }^{46} \mathrm{I}$ focus on key variables consisting of trend, $\mathrm{R} \& \mathrm{D}$, and graduate students, not reporting results for the financial variables, although these are included in the regressions.

Top 20 percent university-fields obtain more research output from R\&D and graduate students than the middle or bottom 40 percent. ${ }^{47}$ Indeed, graduate students in the bottom 40 percent fail to make any significant contribution to research. This implies that their primary duties are to teach and work on thesis research. This and the faculty time needed for dissertation work, reduce the net student contribution to zero in bottom 40 percent university-fields.

Below the top 20 percent the pattern in the trend coefficients suggests that research output grows more rapidly in the within regressions, which include university effects, than in the total regressions that exclude these effects. As before, this pattern could be due to a shift in output toward universities in which growth is less (Adams and Clemmons 2009).

\subsubsection{Faculty Compensation and Wage Structure}

The empirical work concludes with a regression analysis of faculty compensation by professorial rank - or in other words, the academic wage structure. Studying this structure could help us to further understand the financial condition of universities. The dependent variable is the logarithm of wages plus fringe benefits in 1992 dollars at the full and assistant professor ranks. ${ }^{48}$ These are university-wide averages, since HEGIS, which is their source, does not collect wage data by university-field. Since compensation is an average I cannot estimate a typical wage equation where wages are a function of education, experience, and tenure. But faculty quality is reflected in the logarithm of the university-wide R\&D stock per faculty, the logarithm of tuition revenue per faculty (private schools) or tuition plus state appropriations per faculty (public schools), the logarithm of endowment per faculty, and the financial duress indicators, auxiliary/total revenue and

46. Following section 1.4 , top 20 percent regressions include the top five in astronomy; the top 15 in biology, medicine, and engineering; and the top 10 in all other fields. Middle 40 percent regressions include the next 10 in astronomy; the next 30 in biology, medicine, and engineering; and the next 20 in all other fields. Bottom 40 percent regressions include the bottom 10 in astronomy; the bottom 30 in biology, medicine, and engineering; and the bottom 20 in all other fields.

47. These results are similar to findings for top ten universities not reported here. The top ten are selected on the basis of top ten citation impact per paper in a set of twenty-one fields during 1981 to 1993 . Schools ranked as top ten most frequently among these fields are considered a top ten university. They include eight private schools (Harvard, Yale, Chicago, MIT, Stanford, Princeton, Cornell, and California Institute of Technology) as well as two public schools (Berkeley and the University of Washington). It should come as no surprise that top 20 percent university-fields predominate in top ten universities.

48. All monetary variables besides R\&D are deflated by the GDP implicit price deflator indexed to 1992 . 
enrollment/faculty. In constructing per capita variables on the right-hand side of the wage equations, I lag the number of faculty to limit division error bias. Besides the aforementioned, I include trend to capture general wage growth, and a cost of living indicator for whether a university is located in a large city (in the United States, a Consolidated Metropolitan Statistical Area). The specification is:

$$
\log \left(\text { Wage }_{j t}\right)=\alpha+\beta_{0} t+\beta_{L} \text { Large City }+\boldsymbol{\beta}^{\prime} \mathbf{x}_{\mathbf{j t}}+u_{j t} .
$$

These are "total" wage regressions that omit university effects because wage variation is insufficient in the within-university dimension to permit a "within" specification.

Table 1.12 contains the results. The dependent variable in columns (12.1) and (12.4) is the logarithm of full professor compensation; in columns (12.2)

\begin{tabular}{|c|c|c|c|c|c|c|}
\hline \multirow[b]{2}{*}{ Variable or statistic } & \multicolumn{3}{|c|}{ Private universities } & \multicolumn{3}{|c|}{ Public universities } \\
\hline & $\begin{array}{l}\text { Full } \\
12.1\end{array}$ & $\begin{array}{l}\text { Asst. } \\
12.2\end{array}$ & $\begin{array}{c}\text { Full-asst. } \\
12.3\end{array}$ & $\begin{array}{l}\text { Full } \\
12.4\end{array}$ & $\begin{array}{l}\text { Asst. } \\
12.5\end{array}$ & $\begin{array}{c}\text { Full-asst. } \\
12.6\end{array}$ \\
\hline Year & $\begin{array}{l}0.0174 * * \\
(0.0031)\end{array}$ & $\begin{array}{l}0.0257^{* *} \\
(0.0031)\end{array}$ & $\begin{array}{l}-0.0083^{* *} \\
(0.0021)\end{array}$ & $\begin{array}{l}0.0139 * * \\
(0.0016)\end{array}$ & $\begin{array}{l}0.0155^{* *} \\
(0.0015)\end{array}$ & $\begin{array}{l}-0.0014 \\
(0.0010)\end{array}$ \\
\hline Large city ( 1 if yes, 0 if no) & $\begin{array}{l}0.098^{* *} \\
(0.025)\end{array}$ & $\begin{array}{l}0.052^{*} \\
(0.024)\end{array}$ & $\begin{array}{l}0.046^{* *} \\
(0.014)\end{array}$ & $\begin{array}{c}0.032 \\
(0.029)\end{array}$ & $\begin{array}{c}0.017 \\
(0.020)\end{array}$ & $\begin{array}{c}0.016 \\
(0.024)\end{array}$ \\
\hline Log (R\&D stock/faculty) & $\begin{array}{l}0.039 * * \\
(0.015)\end{array}$ & $\begin{array}{l}0.054^{* *} \\
(0.017)\end{array}$ & $\begin{array}{l}-0.015 \\
(0.010)\end{array}$ & $\begin{array}{c}0.017 \\
(0.021)\end{array}$ & $\begin{array}{c}0.019 \\
(0.018)\end{array}$ & $\begin{array}{l}-0.003 \\
(0.011)\end{array}$ \\
\hline $\begin{array}{l}\log [(\text { tuition }+ \text { public } * \text { state } \\
\text { appropriations }) / \text { faculty }]^{\mathrm{a}}\end{array}$ & $\begin{array}{c}0.080 \\
(0.057)\end{array}$ & $\begin{array}{l}-0.035 \\
(0.053)\end{array}$ & $\begin{array}{l}0.116^{* *} \\
(0.042)\end{array}$ & $\begin{array}{c}0.137 \\
(0.073)\end{array}$ & $\begin{array}{r}0.121^{*} \\
(0.056)\end{array}$ & $\begin{array}{l}-0.002 \\
(0.037)\end{array}$ \\
\hline Log (endowment/faculty) & $\begin{array}{c}0.040 \\
(0.021)\end{array}$ & $\begin{array}{l}-0.014 \\
(0.023)\end{array}$ & $\begin{array}{l}0.054^{* *} \\
(0.012)\end{array}$ & $\begin{array}{c}0.011 \\
(0.008)\end{array}$ & $\begin{array}{l}-0.003 \\
(0.008)\end{array}$ & $\begin{array}{c}0.013 \\
(0.007)\end{array}$ \\
\hline Auxiliary/total revenue & $\begin{array}{l}-0.068 \\
(0.287)\end{array}$ & $\begin{array}{l}-0.260 \\
(0.245)\end{array}$ & $\begin{array}{c}0.192 \\
(0.148)\end{array}$ & $\begin{array}{l}-0.095 \\
(0.271)\end{array}$ & $\begin{array}{l}-0.329 \\
(0.182)\end{array}$ & $\begin{array}{c}0.206 \\
(0.170)\end{array}$ \\
\hline Enrollment/faculty & $\begin{array}{l}-0.006 \\
(0.003)\end{array}$ & $\begin{array}{l}-0.001 \\
(0.004)\end{array}$ & $\begin{array}{c}-0.005^{*} \\
(0.002)\end{array}$ & $\begin{array}{c}-0.004 \\
(0.003)\end{array}$ & $\begin{array}{c}-0.002 \\
(0.002)\end{array}$ & $\begin{array}{c}-0.002^{*} \\
(0.001)\end{array}$ \\
\hline No. of observations & 485 & 485 & 485 & 879 & 879 & 879 \\
\hline$R^{2}$ & 0.77 & 0.68 & 0.44 & 0.47 & 0.55 & 0.12 \\
\hline Root MSE & 0.078 & 0.088 & 0.053 & 0.108 & 0.093 & 0.068 \\
\hline
\end{tabular}

Notes: Robust, clustered standard error in parentheses. See the text and table 1.3 for data sources and definitions of the variables. Dependent variable is Log (wage + fringe benefits) in equations labeled "Full" for full professors, and "Asst." for assistant professors; it is the difference in the logarithm of wage + fringe benefits for full and assistant professors in equations marked "Full-Asst."

aThe variable "Public" equals 1 if a university is public, and 0 otherwise, so the variable equals the logarithm of tuition for private universities and the logarithm of tuition + state appropriations in public universities.

*** Significant at the 1 percent level.

**Significant at the 5 percent level.

*Significant at the 10 percent level. 
and (12.5) it is the logarithm of assistant professor compensation; and in columns (12.3) and (12.6) it is the difference of the two.

Starting with the results for full and assistant professors, the trend coefficients show that real compensation grows at about 1.5 percent a year, all else equal, but faster in private universities, especially at the assistant professor level, where it grows at 2.5 percent. ${ }^{49}$ Location in a large city raises private school wages by 5 to 10 percent, although it has no significant effect on wages in public schools, probably because state institutions are mostly located outside large cities. For full professors in private universities, R\&D stock and endowment increase compensation. Besides trend, the only significant determinant of compensation in public universities is current revenue consisting of tuition plus state appropriations.

Columns (12.3) and (12.6) display the results for the difference in compensation for full and assistant professors. In the private university column (12.3), we see that location in a large city, tuition, and endowment increase the wage premium for senior faculty, but trend and enrollment/faculty decrease it. In the public university column (12.6), the wage structure is flat across ranks. Together the findings suggest that successful researchers have an incentive to move to private universities that increases with the rank of full professor.

\subsection{Discussion, Synthesis, and Conclusion}

Is the United States losing its preeminence in higher education? The evidence presented in this chapter suggests that in a relative sense it is. Sections 1.2 and 1.3 tell a story of rapid post-war expansion of US universities, followed by a tapering off after 1980. A series of natural experiments took place in the 1930s and 1940s that contributed to this growth. Because of their exogeneity, these early events may in time capture the imagination of researchers studying higher education.

In the early years, growth of US universities was aided by refugee scientists, with foreign graduate students playing a larger role after 1980. Additional early factors that contributed to expansion of US universities include a broadening of access to universities, increased military research during World War II and the Cold War, and the expansion of high technology industries during the post-war period. Since the 1980s we observe more rapid growth of academic research in Europe, and especially East Asia, that implies convergence in world science and engineering and a decline in the US share.

49. The compensation gap between private and public universities rises at the rate of 0.8 percent a year. In simple regressions that include trend and intercept, I find that, relative to the GDP deflator, both full and assistant professor compensation grows at 2.3 percent per year in private universities and at 1.5 percent per year in public universities. Top ten university compensation grows at 2.2 percent per year. $R^{2} \mathrm{~s}$ for these regressions range from 0.3 to 0.5 . 
But this is not the entire story. Most recently, in the 1990s, we observe a slowdown of publication output in the United States. This becomes the central puzzle of the chapter, and sections 1.4 through 1.6 address it using panel data on universities, fields, and years. In section 1.4 we describe the panel, and in section 1.5 we present growth facts concerning US university research. These reveal that much of the slowdown in publication is located in public universities. While R\&D stocks grow more rapidly in public than private schools, current revenues grow more slowly. This suggests that public universities fall behind because of slower growth in their financial resources.

The regression findings in section 1.6 indicate a fairly similar if not perfectly identical production process in public and private universities. On average, both obtain similar increases in scientific papers from similar combined increases in R\&D, graduate students, tuition revenues, and endowment. This is true even though graduate students play a larger role in public universities, perhaps because research is cross-subsidized by teaching assistantships more of the time. In view of this broad similarity, a divergence in research output over time, in which public universities fall behind, can only be accounted for by a lower rate of increase in public university resources, as section 1.5 reveals.

In support of this hypothesis, compensation in private universities rises almost 1 percent a year faster than in public universities. And besides, wages are flat across professorial rank in public universities, whereas they rise noticeably with rank in private universities. All this suggests reasons for top scientists to migrate from public to private universities. Therefore, in several ways slower growth in current revenues in public universities produces slower growth of research as well.

At the same time, (mostly federal) research funding expands at a faster rate in public schools (Adams and Clemmons 2009). Together this tells an interesting story of state and federal policy interactions. Even as (mostly federal) $R \& D$ is expanding, the states are subjected to a portion of rising health care costs under Medicaid. In addition, some are subject to mandated equalization of $\mathrm{K}$ through 12 education expenditures that raise the cost of elementary and secondary education (Murray, Evans, and Schwab 1998). Toward the end of the period some states commit themselves to prepaid tuition plans that are inadequately funded (Rizzo 2006). So growth of mostly federal research dollars is cancelled out by the slower growth of state dollars in public universities.

An obvious question that arises is whether this situation will persist. If it is temporary, then the downward fluctuations of finances of public universities during the 1990s would be compensated by upward fluctuations at a later time, leaving public institutions on the same unaltered trend line with little to be concerned about in the long run. But if the situation is permanent and state funding remains below trend and perhaps increasingly so, then 
top public universities would have to seek alternative sources of funding to begin to catch up to top private universities. They might, for example, seek to obtain freely floating tuition from parents of students anywhere in the world. But this solution seems unlikely given the charters of state universities and ownership of their real assets by the states. More likely is a gradual removal of tuition price controls to in-state families amidst a frank recognition that price caps deny public universities the resources that are essential to a good education. Still another solution revolves around increased commercialization of university inventions as well as increased sales of merchandise and entertainment, though the latter are hardly consistent with the academic missions of these institutions. All these adjustments to the new realities seem destined to occur slowly, so that relative shortfalls of public universities are likely to persist for years to come.

On a worldwide scale, the relatively faster growth of universities in newly industrializing countries will continue. This is because this growth is part of a convergence process in the developing world, in which steady-state incomes and growth rates increase as a function of increases in education and stocks of knowledge. Even if funding problems of US public universities could be resolved through improved mechanisms of finance, the decline in the US share of world science will likely persist.

Yet another possibility arises. All that we have seen in this chapter, which covers more than 80 percent of academic research in the United States, consists of a fixed set of top 110 institutions. Tables 1.8, 1.9, and 1.11 show that these universities are subject to decreasing returns to scale in research, since the sum of the output elasticities of R\&D stock, graduate students, and financial resources is less than one. Since this is the definition of decreasing returns, one might suppose that beyond the efficient scale, more growth could be obtained at less cost by spreading research funds over a wider range of universities. Of course, organizational assets in smaller research institutions are not necessarily the equal of those in top 110 schools. It follows that if sustained growth of research output is the objective, then the challenge is not only that of spreading resources across more schools, but also that of replicating the assets of top universities. At present, growth appears to be more rapid in universities where this kind of replication remains an open question.

\section{References}

Adams, J. D., and J. R. Clemmons. 2009. The growing allocative inefficiency of the US higher education sector. In Science and engineering careers in the United States, ed. R. B. Freeman and D. Goroff, 349-82. Chicago: University of Chicago Press. 
Adams, J. D., J. R. Clemmons, and P. E. Stephan. 2006. Standing on academic shoulders: Measuring scientific influence in universities. Annales D'Economie et de Statistique 79/80:1-30.

Adams, J. D., and Z. Griliches. 1998. Research productivity in a system of universities. Annales D'Economie et de Statistique 49/50:127-62.

Bush, V. 1945. Science: The endless frontier. Washington, DC: US Government Printing Office.

Davie, M. R. 1947. Refugees in America: A report of the committee for the study of recent immigration from Europe. New York: Harper and Brothers.

De Figueiredo, J. M., and B. S. Silverman. 2006. Academic earmarks and the returns to lobbying. Journal of Law and Economics 49 (October): 597-625.

Ehrenberg, R. G. 2002. Tuition rising: Why college costs so much. Cambridge, MA: Harvard University Press.

. ed. 2006. What's happening to public higher education? Westport, CT: Praeger.

Ehrenberg, R. G., M. J. Rizzo, and G. H. Jakubson. 2007. Who bears the growing cost of science at universities? In Science and the university, ed. R. G. Ehrenberg and P. E. Stephan, 19-35. Madison: University of Wisconsin Press.

Fermi, L. 1971. Illustrious immigrants: The intellectual migration from Europe, 19301941. Chicago: University of Chicago Press.

Freeman, R. B. 2006. Does globalization of the scientific/engineering workforce threaten US economic leadership? Innovation Policy and the Economy 6:123-58.

Helpman, E., and P. R. Krugman. 1986. Market structure and foreign trade: Increasing returns, imperfect competition, and the international economy. Cambridge, MA: MIT Press.

Hicks, D. M. 2007. Global research competition affects measured US academic output. In Science and the university, ed. P. E. Stephan and R. G. Ehrenberg, 223-42. Madison: University of Wisconsin Press.

Hsiao, C. 2003. Analysis of panel data, 2nd ed. New York: Cambridge University Press.

Huffman, W. E., and R. E. Evenson. 1993. Science for Agriculture, 1st ed. Ames, IA: Iowa State University Press.

Khan, Z. 2005. The democratization of invention: Patents and copyrights in American economic development, 1790-1920. New York: Cambridge University Press.

Krugman, P. R. 1979. A model of innovation, technology transfer, and the world distribution of income. Journal of Political Economy 87 (April): 253-66.

Mowery, D.C., and N. Rosenberg. 1989. Technology and the pursuit of economic growth. New York: Cambridge University Press.

1998. Paths of innovation: Technological change in 20th-century America. New York: Cambridge University Press.

Murray, S. E., W. N. Evans, and R. M. Schwab. 1998. Education-finance reform and the distribution of education resources. American Economic Review 88 (September): 789-812.

National Research Council. 1995. Research-doctorate programs in the United States: Continuity and change. Washington, DC: National Academy Press.

National Resources Committee. 1938. Research-A national resource, volume I.Relation of the Federal Government to research. Washington, DC: US Government Printing Office.

- 1941. Research - a national resource, volume II.-Industrial research. Washington, DC: US Government Printing Office.

National Science Board. 2002. Science and engineering indicators 2002 (in two volumes). Arlington, VA: National Science Foundation. 
2006. Science and engineering indicators 2006 (in two volumes). Arlington, VA: National Science Foundation.

2008. Science and engineering indicators 2008 (in two volumes). Arlington, VA: National Science Foundation.

Nobel Laureates Facts. Available at: http://nobelprize.org/nobel_prizes/nobelprize facts.html.

Rizzo, M. J. 2006. State preferences for higher education spending: A panel data analysis, 1977-2001. In What's happening to public higher education?, ed. R. G. Ehrenberg, 3-36. Westport, CT: Praeger.

Robbins, C. A., and C. E. Moylan. 2007. Research and development satellite account update: Estimates for 1959-2004, new estimates for industry, regional, and international accounts. Survey of Current Business 87 (October): 49-92.

Shanghai Jiao Tong University, Institute of Higher Education. 2005. Academic ranking of world universities. Available at: http://ed.sjtu.edu.cn/ranking.htm.

Stephan, P. E., and S. G. Levin. 1991. Research productivity over the life cycle: Evidence for academic scientists. American Economic Review 81 (March): 114-32. 1992. Striking the mother lode in science: The importance of age, place, and time. New York: Oxford University Press.

Toole, A. A., and D. Czarnitzki. 2007. Life scientist mobility from academe to industry: Does academic entrepreneurship induce a costly "brain drain" on the not-forprofit research sector? Discussion Paper no. 07-072, Center for European Economic Research, Mannheim, Germany.

US Department of Commerce, Bureau of the Census. 1975. Historical statistics of the United States: Colonial times to 1970, parts 1 and 2. Washington, DC: US Government Printing Office. 